\title{
O convencionalismo metametodológico de Popper: regras constitutivas ou regulatórias?*
}

\author{
Popper's metamethodological convencionationalism: \\ constitutive or regulative rules?
}

\section{Prof. Dr. Alberto Oliva \\ UFRJ \\ aloliva@uol.com.br}

Recebido: $14 / 04 / 2021$

Aceito: 01/08/2021
Este artigo deriva de uma parte do Seminário - Scienza e Gioco: Il convenzionalismo metametodologico e le regole del metodo: costitutive o regolative - ministrado pelo autor no Center for Logic, Language and Cognition da Universidade de Turim (Itália) em 2019.

\begin{abstract}
RESUMO
O artigo busca identificar os traços distintivos do convencionalismo metametodológico perfilhado por Popper com o objetivo de aferir em que medida representa uma embasada alternativa às tradicionais concepções essencialistas de método. Será dada especial atenção à questão do estatuto normativo que Popper confere às regras metodológicas ao encará-las como convenções. Recorreremos à distinção estabelecida por Searle entre regras constitutivas e regulatórias com o fito de avaliar criticamente a proposta de Popper de pensar a ciência como um jogo. Será discutida a questão de se as regras do método caracterizadas como convenções têm a mesma natureza das regras constitutivas - sem as quais os jogos não vêm a existir - ou se cabe concebê-las como regulatórias a ponto de tornar problemática a tese de que a ciência se parece com um jogo. Apontaremos as dificuldades de se classificarem as regras do método de constitutivas com a finalidade de questionar a visão popperiana que atribui à ciência uma funcionalidade submetida a uma normatividade similar à que pode ser detectada na prática de jogos como o xadrez. A comprovação de que é mais adequado conferir o estatuto de regulatórias às regras do método mostrará ser questionável a comparação, tanto em termos funcionais quanto normativos, da ciência com jogo.
\end{abstract}

Palavras-chave: Convencionalismo, método, jogos, normatividade, essencialismo

\section{ABSTRACT}

The article seeks to identify the distinctive features of Popper's metamethodological conventionalism in order to assess the extent to which it represents a well-founded alternative to traditional essentialist conceptions of method. The paper will pay a special attention to the issue of the normative status that Popper assigns to methodological rules in regarding them as conventions. We will draw on Searle's distinction between constitutive and regulatory rules with the aim of evaluating critically Popper's proposal to conceive science as a game. It will be discussed whether the rules of the method characterized as conventions have the same nature as the constitutive rules - without which games do not come into existence - or whether it is appropriate to think them as regulatory to the point of making problematic the thesis that science looks like a game. We will point out the difficulties of classifying the rules of the method as constitutive in order to question the Popperian view that attributes to science a functionality submitted to a normativity similar to that which can be detected in the practice of games such as chess. The finding that it is more appropriate to confer the status of regulatory to the rules of the method will prove to be questionable the comparison, both in functional and normative terms, of science with game.

Keywords: Conventionalism, method, games, normativity, essentialism. 
I might say that chess would never have been invented apart from the board, figures, etc. and perhaps apart from the connection with troops in battle. No one would have dreamed of inventing the game as played with pencil and paper, by description of the moves, without the board and pieces. Still the game could be played either way.

(Wittgenstein, 1979, p. 194)

Pour un observateur superficiel, la vérité scientifique est hors des atteintes du doute; la logique de la science est infaillible et, si les savants se trompent quelquefois, c'est pour en avoir méconnu les règles.

(Poincaré, 1968, p. 23)

\section{A Questão do "Círculo Convencionalista"}

Se por um lado Popper desferiu duras críticas ao convencionalismo tal qual professado, entre outros, por Poincaré e Duhem, por outro, há ingredientes fundamentais em sua obra que permitem rotulá-lo de convencionalista. Isso levou alguns filósofos da ciência - casos de Robert Ackermann, Joseph Agassi, A. J. Ayer e Anthony Quinton - a classificarem Popper de convencionalista sic et simpliciter. Para Lakatos (1977, p. 104), "o falsificacionismo metodológico é um tipo de convencionalismo". Assim como Kuhn rejeita ser chamado de relativista, Popper (1974a, p. 1117) também não se vê como seguidor do convencionalismo. Fato inequívoco é que Popper é um crítico contumaz do que classifica de estratagema convencionalista, mas é assumidamente um defensor do convencionalismo metametodológico. Uma coisa é o convencionalismo que toma a decisão de salvar artificialmente uma teoria contra a qual se encontrou evidência desfavorável, que acredita que as conclusões científicas são em alguma medida convencionais por sempre existirem alternativas, outro bem diferente é o que advoga, à la Popper, que as regras metodológicas nada mais são que convenções.

Sendo assim, é importante evitar confundir o convencionalismo metametodológico com o convencionalismo que aceita, como sublinha Popper (1989, p. 37), que teorias genuinamente testáveis continuem a ser sustentadas mesmo quando se revelam falsas. Destaca Popper que, nesse caso, os admiradores de uma teoria não hesitam em introduzir uma suposição auxiliar ad hoc ou em reinterpretá-la de modo ad hoc a fim de fazê-la èscāpār da refutação. A despeito de reconhecer que esse tipo procedimento é sempre passível de aplicação, Popper o condena porque salva a teoria da refutação ao preço de destruir, ou pelo menos rebaixar, seu status científico. Entende Popper (1959, p. 82) que no caso de "estar nosso sistema ameaçado, a decisão é nossa de jamais o salvarmos por meio de um estratagema convencionalista, cabendo-nos evitar explorar a possibilidade sempre aberta de se alcançar para qualquer sistema escolhido o que se denomina de sua 'correspondência com a realidade'”. Sendo nossa a decisão, cumpre determinar no que podemos estribá-la.

O problema é que a rejeição do convencionalismo de primeira ordem, o que salva artificialmente teorias, pode também se arrimar no convencionalismo metametodológico, de segunda ordem. Isso quer dizer que as decisões convencionais sobre determinados conteúdos - por exemplo, se é o caso de preservá-los - podem ser tomadas apoiando-as em um convencionalismo metametodológico. O que Popper faz é combater uma modalidade de convencionalismo, de primeira ordem, se escorando em outra, de segunda ordem. Nesse caso, regras metodológicas deixam de ser concebidas como imperativos categóricos ou hipotéticos da racionalidade. Ser ou não ser convencionalista diante de conteúdos é uma questão de decisão bem como aderir a determinadas regras do método. Cabendo ao cientista fazer a escolha, isso significa que decidirá ser ou não ser convencionalista no tratamento de conteúdos com base em regras metodológicas que possuem o estatuto de convenções. Destarte, para evitar dispensar tratamento convencional a conteúdos, é proposta a adoção de uma metodologia que, a despeito de formada por convenções, tem legitimidade para vetar isso como se fosse formada por imperativos categóricos da racionalidade. 
O "círculo convencionalista", resultante de se combater o convencionalismo de primeira ordem recorrendo a outro, de segunda ordem, fica claro quando Popper (1959, p. 82) sublinha que "o único modo de evitar o convencionalismo [o de primeira ordem] é por meio de uma decisão: a de não aplicar seus métodos; decidimos que, no caso de uma ameaça a nosso sistema, não o salvaremos por meio de algum tipo de estratagema convencionalista". É importante observar que é a adoção do convencionalismo de segunda ordem que leva o pesquisador a tomar a decisão de renunciar ao emprego de métodos convencionalistas com base nos quais são, por exemplo, introduzidas hipóteses auxiliares, ou acolhidas hipóteses ad hoc, que podem provocar a diminuição da testabilidade.

\subsection{Desafio de Justificar as Regras do Método}

Em seu magnum opus, Popper (1959, p. 49) parte das seguintes indagações: "quais são as regras do método científico e por que precisamos delas? Pode haver uma teoria dessas regras, uma metodologia?" Nas diferentes fases de sua trajetória intelectual, Popper exibe modos variados de encarar a relação entre (sua) filosofia da ciência e história da ciência. Em poucos escritos, Popper (1971, p. 12) apresenta "sua visão de método científico como corroborada pelo desenvolvimento da ciência: a ciência não se desenvolve pela gradual acumulação enciclopédica de informação essencial, como ensinava Aristóteles, mas por um método muito mais revolucionário". Em reiteradas oportunidades, Popper afirma prescindir da história da ciência para dar sustentação às suas teses. Em seu Postscript a Logik der Forschung, publicado da década de 80, Popper (1996, p. xxv) reafirma a posição metodológica que defendera nos anos 30 :

Não encaro a metodologia como uma disciplina empírica, a ser testada, quem sabe, pelos fatos da história da ciência. Trata-se, isto sim, de uma disciplina filosófica, metafísica. Talvez, em parte, até uma proposta normativa. Baseada amplamente no realismo metafísico e na lógica da situação: a situação de um cientista perquirindo a realidade desconhecida por trás das aparências e ansioso para aprender com os erros.

A posição mais repetida por Popper (1996, p. xxxi) é a de que sua "teoria da ciência não pretendeu ser uma teoria histórica nem uma teoria respaldada por fatos históricos ou outros fatos empíricos". Com isso, deixa claro que não se preocupa em escorar sua teoria do método na ciência real. Popper acredita ser a história da ciência melhor entendida e elucidada recorrendo-se às lentes providas por sua filosofia da ciência: "duvido até que exista uma teoria da ciência capaz de lançar tanta luz sobre a história da ciência quanto a teoria da refutação seguida de revolucionária, porém conservadora, reconstrução". Longe de buscar respaldo na história da ciência, a filosofia da ciência popperiana se considera a mais apta a dar sentido aos fatos que marcam o evolver da ciência em geral:

Minha tese geral é a de que nosso conhecimento cresce, via de regra, pela descoberta de que cometemos um erro ou de que inconscientemente aceitamos uma teoria errada. Minha teoria é uma teoria lógica ou uma regra metodológica (uma teoria normativa) que estatui que devemos procurar casos que possam contar como refutações. Sendo assim, minha metodologia não tem a pretensão de ser uma teoria empírica. (POPPER, 1998, p. 209)

Em escritos posteriores a Logik der Forschung, Popper propõe o cotejo de sistemas metodológicos rivais sem deixar de conceber as regras do método como convenções. Esse Popper perfilha um convencionalismo metametodológico que dá a impressão de acreditar que o valor das regras do método é 'empiricamente' aferível. Por essa óptica, as convenções são pensadas como avaliáveis em termos da confiabilidade dos resultados que permitem alcançar. Tenha-se, no entanto, presente que esse Popper procura confrontar, como apontam Nola \& Sankey (2000, p. 18), sua metodologia com rivais formulando "juízos históricos sobre o que foi, e o que não foi, grande ciência”. Sabidamente desprezador da 'normal science, Popper busca selecionar na história da ciência o que aponta como seus "momentos heroicos”, casos emblemáticos de refutação de teorias. 


\subsubsection{0 'Garfo de Hume' e as Soluções de Popper e dos Empiristas Lógicos}

No último parágrafo do An Enquiry concerning Human Understanding, Hume (1952, p. 509) desqualifica, de modo iconoclasta, como sofisma e ilusão, digno de ser lançado às chamas, o que não é nem raciocínio de tipo lógico nem teoria estribada na experiência. É claro que se para ter valor cognitivo o raciocínio tem de ser logicamente demonstrativo ou fundado nos fatos, então as regras do método enfrentam sérios problemas para ter sua formulação e sua aplicação epistemicamente justificadas. Para ser possuidora de valor cognitivo, uma teoria do método precisaria se compor de máximas comportamentais logicamente justificáveis ou se escorar empiricamente na identificação do conjunto de normas e procedimentos de facto postos em prática pela comunidade científica. Rejeitando tanto a concepção lógica quanto a empírica de regras do método, Popper apresenta o convencionalismo metametodológico como a terceira via remanescente.

Recusando a tentativa kantiana de superar o "dualismo epistemológico" entre relations of ideas e matters offact pela introdução do juízo sintético a priori, o empirismo lógico e Popper representam uma volta a Hume. Mesmo se dizendo em concordância com teses fundamentais da epistemologia kantiana, Popper (1959, p. 29) ressalva que "não foi bem sucedida a engenhosa tentativa de prover uma justificação a priori para os enunciados sintéticos". Por serem insuscetíveis de verificação/confirmação, e não poderem ser justificados em termos de cogência lógica, os enunciados prescritivos geram dificuldades especiais de justificação. É complicada a tarefa de validar as regras do método tendo em vista que postulam um poder normativo-funcional ao qual não se tem como atribuir estatuto cognitivo. Não sendo nem verdadeiras nem falsas, não sendo defendidas nem como imperativos categóricos nem como imperativos hipotéticos da racionalidade, as normas colocam o desafio de identificar sua fonte e de prover sua justificação. Não sendo possível atribuir-lhes valor cognitivo, Popper só vislumbra a opção de concebê-las como convenções. O convencionalismo professado por Hume com relação à natureza das regras que organizam a vida social foi deslocado para a ciência por Popper.

A despeito de se apresentar como destruidor do empirismo lógico, Popper (1974b, p. 69) deve muito mais ao empirismo lógico do que se propõe a reconhecer. Seu convencionalismo metametodológico é francamente caudatário de posições que já tinham sido defendidas por Carnap. Sem falar que Reichenbach também na década de 30 defende teses muito próximas das de Popper. Em seu Überwindung der Metaphysik durch Logische Analise der Sprache publicado na Erkentnis em 1932, dois anos antes da Logik der Forschung, Carnap deixa clara sua adesão" ao "dualismo epistemológico" para o qual só se pode conferir estatuto cognitivo ao lógico e ao empírico, jamais a normas e valores. Só ciências particulares como a psicologia ou a sociologia podem formular proposições sobre normas e valores portadoras de importe cognitivo. Carnap (1959, p. 77) encara as normas, mesmo as que se pretendem epistêmicas, como desprovidas de validade objetiva em virtude de serem insuscetíveis de verificação empírica ou incapazes de serem deduzidas de enunciados empíricos. A constatação de que normas não têm como ser veiculadas por meio de enunciados possuidores de significado cognitivo torna crucial identificar que tipo de legitimidade podem alcançar. Com uma pitada de Wittgenstein I, Carnap chega a declarar que normas sequer podem ser afirmadas (por meio de um enunciado provido de significado).

O fato de as normas não serem empiricamente respaldáveis, nem logicamente justificáveis, fez emergir com força a proposta de tratá-las como convenções, como faz Carnap ao se mostrar inclinado a encará-las como simples 'propostas'. Em outro trabalho da década de 30, Carnap (1949, p. 278) reitera sua posição sobre os discursos normativos e valorativos: "as sentenças espúrias da metafísica, da filosofia dos valores, da ética (na medida em que é tratada como uma disciplina normativa e não como uma investigação psicossociológica dos fatos) são pseudossentenças; carecem de conteúdo lógico, são apenas expressões de sentimentos que, por sua vez, estimulam sentimentos e tendências volitivas por parte do ouvinte". Mesmo sem esposar de modo abrangente o convencionalismo metametodológico, à maneira de Popper, Carnap encara as normas como convenções quando formula o Princípio da Tolerância para o qual determinadas normas ou convenções não podem ser impostas como as únicas aceitáveis. No mesmo ano da publicação da Logik der Forschung, Carnap (1949, p. 51 e p. 124) assim apresenta o Princípio da Tolerância: "não é de nossa alçada estatuir proibições, mas chegar a convenções [...] na lógica, não há lugar para avaliações morais, todos têm a liberdade de construir, a 
seu bel-prazer, sua própria lógica, sua própria forma de linguagem; tudo que se exige é que no caso de alguém desejar discutir sua escolha deve enunciar seus métodos de modo claro; essa é uma questão de escolha como o são todas as questões concernentes à forma de linguagem escolhida". Em Der logische Aufbau der Welt, publicado em 1928, Carnap (1967, p. 289) já chamara a atenção para a dimensão convencional: "o primeiro objetivo, o da construção de objetos, é seguido por um segundo, a saber, a investigação das propriedades e relações não construtivas dos objetos; o primeiro objetivo é atingido por meio de convenções, o segundo pela experiência”. Para a teoria da construção, tal qual a caracteriza Carnap, há dois componentes envolvidos na produção de conhecimento: o convencional e o empírico. Contra Kant, Carnap sustenta que "não há, portanto, nenhum sintético a priori”. No processo real da ciência, resume Carnap, "esses dois objetivos estão quase sempre interconectados".

Apesar de contrapor seu convencionalismo metametodológico ao naturalismo, que sustenta ser abraçado pelo empirismo lógico, Popper (1959, p. 53) se viu obrigado a reconhecer em nota de rodapé, redigida enquanto o Logik der Forschung estava na fase de prova de autor, que sua posição não era muito diferente da de Carnap: "a visão aqui apresentada de modo sucinto - para a qual é questão de decisão o que deve ser chamado de 'enunciado genuíno' e o que deve ser chamado de 'pseudoenunciado sem sentido' - tem sido por mim sustentada por anos. (assim como a visão de que a exclusão da metafísica é igualmente uma questão de decisão)". Popper reconhece a proximidade de sua posição com a de Carnap quando ressalva que "a crítica que faço aqui ao positivismo (e à visão naturalista) não se aplica mais quando se leva em conta o Logische Syntax der Sprache de 1934 de Carnap no qual é adotado o ponto de vista de que todas essas questões repousam em decisões (o 'princípio da tolerância')". Em obra bem posterior, Popper (1989, p. 279) volta a apontar "outros pontos de concordância" com Carnap como, por exemplo, "a tese de que há um componente convencional na aceitação ou rejeição de qualquer sentença sintética".

No entanto, Popper deveria ter reconhecido que a defesa de teses convencionalistas não se faz presente apenas na Logische Syntax der Sprache. O teor dessa nota poderia ser estendido a Reichenbach - fundador da Gesellschaft für Empirische Philosophie - que também na década de 30 defende posições com pontos importantes de convergência com o convencionalismo metametodológico. Reichenbach apresenta as questões referentes aos objetivos da ciência e, por extensão, ao método científico, como questões de gosto pessoal ou expressão de preferência, como 'bifurcações volitivas', já que não podem ser justificadas nem em termos puramente lógicos nem em termos empíricos. A importante discordância com Popper aparece quando Reichenbach afirma ser "obvio que essa decisão não é uma convenção porque as duas concepções adotadas com base em diferentes postulados referentes aos objetivos da ciência não são equivalentes, uma vez que se trata de uma bifurcação". O conceito de bifurcação destaca que a opção por um caminho se faz em detrimento de outro e que cada um leva à perseguição de uma meta diferente e à chegada a diferentes destinos:

Bifurcações volitivas de um tipo importante se fazem presentes já no limiar da ciência: são decisões concernentes ao objetivo da ciência. Qual o propósito da investigação científica? Esta não é, logicamente falando, uma questão de caráter veritativo, mas uma decisão volitiva. A decisão determinada pela resposta a esta questão possui natureza de bifurcação. Se alguém nos diz que estuda ciência por prazer e para preencher suas horas de lazer, não podemos apresentar a objeção de que esse raciocínio é "um enunciado falso". Mesmo porque não é sequer um enunciado, mas uma decisão e todos têm o direito de fazer o que quiserem [...] nos livros e discursos a palavra "ciência" é sempre vinculada a "descobrir a verdade", às vezes a "predizer o futuro". Contudo, logicamente falando, trata-se de questão volitiva. (REICHENBACH, 1976, p. 10)

Mesmo sendo realistas com relação aos objetivos da ciência, Popper e Reichenbach não indicaram até os anos 50 - como assinala Laudan (1996, p. 16) - a busca da verdade como o fim a ser perseguido em virtude de o encararem como uma convenção. No que diz respeito ao modo de lidar com a problemática das regras metodológicas, Popper tem menos divergências com os empiristas lógicos do que apregoa. Mesmo porque 
seu convencionalismo metametodológico também ratifica tacitamente o "dualismo epistemológico" humeano para o qual a formulação de regras não tem como representar uma forma de conhecimento. Não podendo as regras do método ser justificadas como imperativos categóricos da racionalidade ou como comandos lastreados na ciência tal qual praticada, a saída encontrada por Popper e por alguns empiristas lógicos foi concebê-las como convenções.

Se só as ciências empíricas estão aptas a produzir proposições sintéticas, verificáveis ou refutáveis, se a lógica fica confinada às verdades analíticas, o desafio consiste em apresentar as regras do método de um modo que propicie justificar sua enunciação. Soa paradoxal que regras reputadas indispensáveis à geração de conhecimento sejam consideradas desprovidas de valor cognitivo. É missão das mais complicadas defender a opção por tal ou qual conjunto de estipulações metodológicas caso não tenham como ser justificadas nem lógica nem empiricamente. Por endossarem o "garfo de Hume", Popper e empiristas lógicos como Carnap e Reichenbach vislumbram como saída encarar as regras como convenções [ou bifurcações]. Com isso, a metodologia deixa de ter a prerrogativa de formular os imperativos categóricos da racionalidade, mas não a de enunciar as normas em condições de moldar a conduta na pesquisa.

O convencionalismo reflete o fato de a metodologia ser vista como problemática em virtude das sérias dificuldades para se avaliar o que recomenda ou estatui. Não se tendo como qualificar a metodologia como uma forma de conhecimento, surge o desafio de como justificar a opção por algumas regras e procedimentos em detrimento de alternativas. Insuscetíveis de receber um valor de verdade ou de ser validadas de modo lógico, máximas de conduta intelectual enfrentam sérias dificuldades para comprovar sua indispensabilidade. A preferência por determinadas regras está longe de poder ser facilmente justificada em virtude de ser necessário, subsistindo competição, demonstrar que são superiores às alternativas. Rechaçando tanto a visão que encara as normas metodológicas como imperativos categóricos quanto a que as concebe como imperativos hipotéticos da racionalidade, Popper as caracteriza como convenções sem deixar de atribuir poder normativo tácito às que escolhe. Associando de modo questionável ao empirismo lógico uma concepção naturalista de método, Popper (1959, p. 53) a ataca alegando que carece de espírito crítico: "seus defensores não conseguem perceber que sempre que acreditam ter descoberto um fato apenas propõem uma convenção a ponto de a convenção se mostrar suscetível de se transformar em dogma”. A recusa a encarar as regras do método como fatos da prática científica ou como imperativos categóricos da racionalidade para investi-las do status de convenção afasta Popper do empirismo lógico menos do que tanto apregoa:

Essa visão, de acordo com a qual a metodologia é uma ciência empírica - um estudo do comportamento real dos cientistas ou dos procedimentos efetivamente empregados na ciência - pode ser descrita como 'naturalista' [...] o que chamo de 'metodologia' não deve ser tomado como uma ciência empírica. Não acredito que seja possível decidir, usando os métodos de uma ciência empírica, questões controversas como a de se a ciência realmente usa ou não um princípio da indução. E minhas dúvidas aumentam quando lembro que o que deve ser chamado de 'ciência', e quem deve ser chamado de 'cientista', permanecerá sempre uma questão de convenção ou decisão. (POPPER, 1959, p. 52)

Para Popper (1959, p. 51), as críticas feitas por membros do Círculo de Viena às suas ideias se baseiam no pressuposto segundo o qual "é impossível uma teoria do método que não seja nem ciência empírica nem pura lógica, já que aquilo que se situa fora desses dois domínios não passa de completo contrassenso". Popper (1959, p. 52) rejeita que "se a metodologia não é lógica, então, como concluem [os empiristas lógicos], deve ser um ramo de alguma ciência empírica - no caso, a ciência, digamos, do comportamento dos cientistas em atividade". Essas avaliações popperianas não fazem justiça às posições de alguns empiristas lógicos. A vingar a óptica convencionalista de Popper, sistemas metodológicos rivais não têm como invocar o respaldo nos fatos - nos modos com que a ciência é efetivamente praticada - porque as normas vigentes podem expressar apenas uma preferência circunstancial determinada, por exemplo, pelo estágio em que se encontra a pesquisa em uma ciência. A tentativa de acompanhar o que fazem os cientistas, de como se comportam in loco, em 
alguns autores se transforma na sutil operação de justificar a transição do é para o deve. Um dos problemas enfrentados pelo naturalismo metametodológico é o de que aquilo que é detectado na ciência real já representa, per se, a opção por certas normas e valores. Em contraposição, o convencionalismo metametodológico tem de lidar com a espinhosa questão de que as regras escolhidas não são as únicas possíveis por mais que possam, em um contexto específico, despontar como as mais adequadas.

Como alguns empiristas lógicos consideravam a atribuição de finalidades à ciência fruto de escolhas, e não de como a ciência é na realidade produzida, reconheciam ter diante de si o desafio de justificar as convenções sem poder a elas atribuir valor cognitivo. Sendo assim, é improcedente a acusação de Popper de que são "naturalistas", de que ambicionam derivar o quid juris do quid facti, extrair as regras do método dos fatos constitutivos das práticas científicas. As críticas desferidas por Popper ao que chama de naturalismo se aplicam menos ao empirismo lógico e mais a pensadores como Quine, Putnam, Hacking e Rorty. A despeito de optarem por molduras filosóficas bem diferentes, todos defendem que ao estudioso da ciência só cabe descrever os métodos de facto colocados em uso pelos cientistas. O naturalismo pode ser questionado, entre outras razões, por fazer referência apenas às práticas das ciências maduras, ignorando as ciências marcadas por disputas internas vinculadas à adoção de conflitantes sistemas metodológicos. Mesmo quando se trata de acompanhar as ciências naturais, os naturalistas jamais lograram identificar de modo consensual os procedimentos metodológicos por elas efetivamente postos em prática. Quando Durkheim (1967, p. xiv) defende que "o sociólogo se imbua do espírito dos físicos, químicos e fisiologistas" não indica de que modo efetivamente procedem. Seu naturalismo equivale, no fundo, à proposta de adoção de uma metodologia empirista derivada de Bacon e, principalmente, de Mill.

Para escapar da selva da diversidade de procedimentos presente nas desniveladas ciências, o naturalismo metametodológico não advoga que as regras do método sejam derivadas do acompanhamento das práticas de pesquisa presentes nas Escolas e Subescolas aninhadas nas disciplinas sociais. O fato de quase toda a filosofia da ciência do século XX ter gravitado em torno da física é também consequência da tentativa de contornar a espinhosa problemática da indomável variedade do que se tem genericamente chamado de ciência. A polêmica metodológica endêmica no interior até mesmo de uma mesma Escola integrante de uma ciência social desorienta os que desejam seguir os passos da ciência real. O que o naturalista metodológico justificadamente pede é que se renuncie à empreitada de elaborar metodologias normativas cujas estipulações não têm como ser objetivamente avaliadas por se sobreporem à ciência tal qual praticada. Popper rejeita o que chama de concepção naturalista de metodologia por considerá-la desprovida de senso crítico e por entender que, no fim das contas, nada mais que propor convenções por mais que tente legitimá-las como derivadas da ciência de "carne e osso". Para Popper, a crítica ao naturalismo "se aplica não só ao critério de significatividade que o acompanha bem como à sua ideia de ciência e, de consequência, de método empírico":

Positivistas normalmente encaram o problema da demarcação de uma forma naturalista; interpretam-no como se fosse um problema de ciência natural. Em vez de abordá-lo como se envolvesse a tarefa de propor uma convenção adequada, acreditam que têm de descobrir uma diferença, existente na natureza das coisas, por assim dizer, entre a ciência empírica por um lado e a metafísica, por outro. (POPPER, 1959, p. 35)

A tese popperiana de que as regras metodológicas estão intimamente articuladas e que devem ser atreladas a um critério de demarcação/cientificidade é compatível com o que defendem os representantes do empirismo lógico supracitados. O mesmo se pode dizer da advertência de Popper (1959, p. 54-5) de que a conexão entre as regras nunca é estritamente dedutiva ou lógica. Sendo as regras construídas com o objetivo de assegurar a aplicabilidade do critério de demarcação, sua formulação e justificação dependem da existência de uma regra prática de tipo superior. O exemplo dado é o de que teorias que decidimos não submeter a novos testes passam a ser tratadas como insuscetíveis de refutação. A conexão sistemática entre as regras torna apropriado, no entender de Popper (1959, p. 54-5), falar de uma teoria do método: "reconhecidamente, os pronunciamentos dessa teoria são, como nossos exemplos mostram, em sua maior parte convenções de um 
tipo bastante óbvio". Apesar de afirmar que "verdades profundas não deverem ser esperadas da metodologia", Popper acredita que ela pode nos ajudar em muitos casos a esclarecer a situação lógica, e até mesmo a resolver alguns problemas de grande alcance, que até agora têm permanecido intratáveis; um deles, por exemplo, é o problema de decidir se um enunciado de probabilidade deve ser aceito ou rejeitado".

Se, por um lado, as convenções costumam ser socialmente impositivas, por outro, não se justifica reputá-las epistemicamente cogentes. Em razão de envolver expressão de preferência, e eventual adesão a um quadro valorativo, a aceitação ou rejeição de uma convenção não tem como ser apresentada como fruto de compulsão epistêmica, como resultante do endosso de um imperativo categórico da racionalidade. 'Convenção' vem do latim convenio, que significa colocar-se de acordo com relação a alguma coisa. A questão é saber qual a natureza do acordo, do consensus gentium, uma vez que escolhas e preferências - independentemente de se manifestarem na ciência ou alhures - não são julgáveis por fatos. A defesa de uma regra metodológica, como a que estatui que uma teoria científica deve ser rejeitada caso entre em conflito com a experiência, com um enunciado básico unanimemente aceito, torna necessário abordar a questão da avaliação metametodológica, a voltada para a identificação do status conferido ao que se propõe como regra metodológica. Visto que a ciência requer regras para ser praticada no âmbito de comunidades, que se organizam em torno de determinadas funcionalidades e finalidades, o que cabe discutir é se as regras, não podendo ser validadas como conhecimento, não podendo ser justificadas nem lógica nem empiricamente, requerem - no caso de passarem a ser vistas como convenções - uma abordagem predominantemente psicossocial a ponto de se tornar imperioso o recurso às ciências sociais em detrimento das teorias filosóficas do método.

\subsection{A Ciência como Expressão da Razão Pura ou como Puro Jogo}

O convencionalismo metametodológico rechaça a ideia de compulsão epistêmica provocada pelo irrestrito acatamento dos imperativos categóricos da racionalidade. Com isso, as regras do método deixam de ser vistas como tendo estatuto normativo idêntico ao das regras morais concebidas de modo deontológico. A descrença em imperativos categóricos da racionalidade, o abandono da ideia de compulsão epistêmica, mina o poder condutor conferido às normas pelas metodologias tradicionais. Deixada de lado a compulsão epistêmica gerada pela observância de normas supostamente cogentes, passa a ser fundamental identificar a natureza das máximas de conduta intelectual que regem, se é que o fazem, a atividade de pesquisa. Se às regras do método não se atribui o estatuto de imperativos categóricos da racionalidade, se deixam de ser vistas como capazes de provocar compulsão epistêmica, cumpre explicar com base em que são aceitas ou rejeitadas as postulações de conhecimento. O desafio consiste em apresentar um resultado como epistemicamente justificado sem infundir compulsoriedade de tipo "deontológico", ou ao menos eficácia "teleológica", aos procedimentos metodológicos empregados.

A filosofia da ciência tradicional sempre mostrou propensão a vincular a racionalidade ao respeito incondicional a determinados imperativos metodológicos. A excelência das construções explicativas e de resultados específicos era vista como resultante da observância de regras tidas como conditio sine qua non para a geração de conhecimento. Fruto do respeito a procedimentos e regras que encarnam a racionalidade, o endosso ou rechaço de hipóteses, teorias ou explicações, nada teria a ver com convenções. Peirce (1958, p. 133) expõe como opera a compulsão epistêmica que impele o pesquisador para certas conclusões e que torna possível o compartilhamento de resultados entre os diversos estudiosos: "diferentes mentes podem partir de visões as mais antagônicas, mas o progresso da investigação faz com que sejam arrastadas por uma força que, situada fora delas, as leva em direção a uma mesma conclusão". Entende Peirce que "essa atividade do pensamento que nos leva não para onde desejamos, mas para uma meta predefinida, se parece com uma operação do destino".

A concepção de racionalidade autônoma associada à compulsão epistêmica foi fortemente questionada no século XX. Muito se usou a noção de 'jogo’ com esse propósito. Antes de o Wittgenstein II (1968, $\$ 3, \S 7$, $\$ 23, \$ 24 \mathrm{e} \$ 31$ ) recorrer ao conceito de 'jogo' para formular questões concernentes à natureza da linguagem 
- sua estrutura, regras, peculiaridades, fundamentos - e do processo que permite aprendê-la, Popper aplicara tal noção à ciência. Levando longe o estabelecimento de analogias funcionais entre ciência e jogo, Popper pretendeu elucidar aspectos fundamentais da natureza da racionalidade científica. Cabe avaliar se Popper foi bem sucedido em seu projeto de identificar o que atividades tão diferentes - como ciência e jogo - podem ter de parecido, ou igual, em termos funcionais, operacionais ou procedimentais, que justifique propugnar que uma é como a outra.

É fundamental ter presente que Popper almeja não apenas estabelecer comparações pontuais entre ciência e jogo com objetivos didáticos, mas sim mostrar que se submetem a um tipo de regra, caracterizável como convencional, que os leva a apresentarem funcionalidades similares. Organizados e praticados com base em regras supostamente portadoras do mesmo tipo de normatividade, ciência e jogo exibiriam operacionalidades muito parecidas. Contra o velho essencialismo metametodológico, Popper não se limita a encarar a ciência como tendo traços gerais - semelhanças de família - que a tornam parecida com jogo. Caso se comprove que a ciência ostenta uma funcionalidade similar à dos jogos e que está submetida a um sistema normativo pouco diferente do presente nos jogos, então merece ser qualificada de idealizada a racionalidade modelar que tem sido atribuída à ciência. É manifesto que conceber a ciência como um jogo representa um afastamento das visões tradicionais de ciência e de método, as quais tinham chegado a paralisantes contraposições, pois, como observa Bachelard (1949, p. 565), "empirismo e racionalismo continuaram um diante do outro, mas sem a capacidade de alcançar a verdadeira cooperação filosófica ou o mútuo enriquecimento".

Uma alternativa à visão que encara as regras metodológicas como imperativos categóricos da racionalidade é concebê-las como imperativos hipotéticos. Nesse caso, trata-se de aferir que finalidades diferentes as diversas regras metodológicas permitem perseguir. Como propõe Laudan (1996, p. 133), a norma - a ação metodológica recomendada - estaria conectada ao fim visado e à eficácia na geração de resultados bem sucedidos. Para Laudan (1984, p. 34), "em geral, concordarmos em regular uma atividade (seja ela a ciência, o xadrez ou debate parlamentar) por meio de um conjunto específico de regras por pensarmos que essas regras nos permitirão alcançar os fins ou as metas que definem o telos da atividade". Para chegar a essas regras metodológicas seria fundamental identificar, principalmente por meio do acompanhamento da história da ciência, que procedimentos têm-se revelado indispensáveis à obtenção de resultados exitosos e para a conquista dos fins visados. Defendendo regras como imperativos hipotéticos, respaldados por seu sucesso no passado, Laudan advoga que "se as ações de determinado tipo, $m$, têm consistentemente promovido certos fins cognitivos no passado, enquanto as ações rivais, $n$, não têm conseguido alcançá-los, então se presume que as ações futuras que seguem a regra "se teu objetivo é $e$, deves fazer m" têm mais probabilidade de promover esses fins que as ações baseadas na regra "se seu objetivo é $e$, deves fazer n"'. Há nessa proposta a defesa de um raciocínio indutivo de segunda ordem, estribado no acompanhamento da história da ciência, que é liminar e peremptoriamente rechaçado por Popper. Sem falar que Popper também a rechaça como naturalista.

Depois de proclamar que "a essência da ciência é a pesquisa", Heidegger (1977, p. 118) em Holzwege indaga: "qual a essência da pesquisa?” A resposta de Popper é a de que a pergunta pela essência é equivocada porque a ciência se parece com um jogo no sentido de que ambos exibem propriedades normativo-operacionais do mesmo tipo. Sendo esse o caso, a boa prática da ciência depende apenas da adoção das convenções apropriadas. À luz do convencionalismo metametodológico, a ciência não se confunde com um conjunto de propriedades e procedimentos que, uma vez identificados como sua essência, podem ser sempre invocados para distinguir ciência de não ciência ou pseudociência. A escolha - e não a identificação - de certos procedimentos confere à ciência uma identidade. A ciência não se destaca pela posse imanente de determinadas propriedades, mas pelas que lhe são atribuídas para bem praticá-la. A visão de que é o conjunto de atributos conferidos à ciência que permite demarcá-la do que não é ciência leva Popper a dar às regras do método o status de convenções. Passa a ser questão de decisão tomar certos procedimentos e propriedades como distintivos da ciência. A concepção decisionista de (meta)método é fruto da crença de que as propriedades essenciais e invariantes da ciência não têm como ser identificadas porque simplesmente não existem. Se há diaphonia (meta)metodológica não é fruto da incapacidade de apreender as regras bem sucedidas em uma ciência modelar como a física, mas de se adotarem as convenções erradas. 
Na visão de McMullin (1978, p. 233), o logicismo - que pode assumir duas formas principais: o verificacionismo e o falsificacionismo - "é a metametodologia que sustenta que os métodos de avaliação de teorias têm o status de regras lógicas, e que a metodologia se reduz à lógica aplicada". Tal qual defendido por Popper, o falsificacionismo carece do caráter logicista que lhe atribui McMullin. Mesmo porque é difícil conciliar convencionalismo metametodológico e logicismo. Conceber a ciência como um sistema de regras similar ao de um jogo é incompatível com a ideia de que se trata de uma atividade de pesquisa submetida o tempo todo a requisitos lógicos cogentes. As regras que tornam possível a existência de um jogo não são lógicas por mais que apresentem uma consistência sistêmica. Na verdade, a forma convencionalista de encarar as regras do método combate a tendência, arraigada entre os filósofos, a adotar enfoques epistemologistas e logicistas bem como o naturalismo que privilegia o acompanhamento das práticas de pesquisa para delas derivar as "regras do método".

Pandit (1991, p. 120) observa que Popper pretende "evitar desde o início questões essencialistas tais como: O que é a ciência empírica? Qual sua identidade estrutural do ponto de vista epistemológico/metodológico?" No entanto, como assinala Pandit, ao dizer-nos que "há uma coisa como o jogo empírico da ciência que, como o jogo de xadrez, é definível por meio de suas convenções", Popper deixa intocadas as questões essencialistas. Ao identificar ciência com jogo, Popper busca trocar uma pergunta essencial por outra funcional. Substituir a pergunta o que é a ciência pela "o que é um jogo?" dificilmente torna a resposta mais fácil, por mais que à primeira vista a tradicional e complexa busca da essência da ciência desponte irrespondível diante das enormes diferenças subsistentes entre os vários domínios da pesquisa.

Proclamando a inexistência de essências, o convencionalismo metametodológico deveria deixar em aberto a possibilidade de adoção de procedimentos alternativos aos escolhidos. Como ressalta Laudan (1990, p. 46), "as convenções poderiam ser diferentes, uma vez que é isso que as torna convenções". No entanto, Popper não apresenta um posicionamento metodológico, como seria de esperar, que se mostre tolerante para com as alteridades. Este é um ponto importante porque seria lícito esperar que um convencionalista metametodológico propusesse seu sistema de regras como um dentre outros possíveis ou admissíveis. Como destaca Pandit, o convencionalismo metametodológico não hesita em extrair a parte crucial de sua força de justificação da estipulação de que "quem decide adotar regras como as indutivistas se retira do 'jogo' da ciência". Tal veredicto suscita a seguinte indagação de Pandit: "é totalmente facultado a alguém adotar essas regras [indutivistas] ou as incompatíveis com as regras popperianas sob a condição (popperiana) de que a própria decisão de fazê-lo implica retirar-se do 'jogo' da ciência?” A resposta popperiana é claramente negativa e, como sublinha Pandit, "a intolerância metodológica que essa posição acarreta está em contradição com o convencionalismo de Popper, que advoga que as regras metodológicas são apenas convenções e questão de decisão":

Por um lado há a visão explicitamente adotada de que regras metodológicas - em seu caso, todo um conjunto hierarquizado de regras com o critério da falsificabilidade no vértice devem ser tratadas como convenções e, portanto, como questões de decisão; por outro, há a visão, mantida implícita no que ele diz, segundo a qual na ciência, ou na teoria científica, certas características universais invioláveis se situam para além dos limites da variação metodológica devido às decisões metodológicas que os cientistas podem tomar ao longo do tempo. (PANDIT, 1991, pp. 204-5)

Quando lida com a questão da metodologia adequada ao estudo dos fatos sociais, Popper (1976, p. 69, p. 79 e p. 87) desqualifica, entre outros, o enfoque holista com base na alegação de que "viola os princípios do método científico" e de que "planeja estudar nossa sociedade por meio de um método impossível". Ademais, o método é, para Popper, o "de todas as ciências empíricas". É manifesta a tensão entre o convencionalismo, que em tese deveria ser tolerante, e o falsificacionismo com sua pretensão ao "exclusivismo", à imposição universal de determinado conjunto de regras contra as alteridades. O convencionalismo metametodológico popperiano não se mostra afinado com aquilo que deveria caracterizá-lo: o respeito à diferença. A proliferação de metodologias resguardadas de avaliações peremptórias deveria decorrer da visão de que é uma questão de 
decisão a escolha dos procedimentos a usar. Se o que está em jogo é a escolha de um sistema de convenções, para o qual há alternativas cogitáveis, nada justifica absolutizá-lo. Torna-se problemático entronizar um sistema de regras em virtude de não se poder mais justificar a preferência com base na autoridade da razão pensada como estribada em um tipo de monopólio legislativo como o postulado pela tradição normativista da filosofia da ciência.

Caso inexistam procedimentos essenciais inevitáveis para se chegar ao conhecimento, não é desarrazoado propor que diferentes caminhos sejam experimentados de modo a evitar que se conceda autoridade metodológica especial a um deles. Existindo vários procedimentos admissíveis, sem que nenhum tenha como alijar os demais pela comprovação inequívoca de sua superioridade, é como se todos fossem prescindíveis. Levado às últimas consequências, o convencionalismo metametodológico deveria ser um defensor da pluralidade de procedimentos e não um concessor de dissimulado monopólio "deôntico" a determinado conjunto de regras. Desse modo, respeitaria a diversidade de procedimentos encontráveis nas várias e desniveladas ciências. Ademais, resulta complicado comparar regras metodológicas se é mera questão de decisão a escolha de umas em detrimento de outras. Na falta de procedimentos e propriedades caracterizáveis como formadores de uma identidade, ou encarados como traços constitutivos de uma essência, os que são hoje destacados podem, em princípio, vir a ser substituídos por outros. Uma vez que para as convenções propostas podem ser sempre apresentadas, ao menos em teoria, alternativas não se justifica colocar no pedestal um conjunto de procedimentos metodológicos. Não sendo a constelação de convenções abraçada a única possível e admissível, a opção por ela é fruto de preferência, não de compulsão epistemológica ou de imposição metacientífica derivada do acompanhamento da ciência real.

O risco de proliferação de convenções, sem crivo racional de seleção capaz de taxativamente definir as mais aptas a gerar conhecimento, torna necessário mostrar que a ciência só pode ser (bem) feita pela adoção de algumas delas. É questionável que o recurso a uma metaconvenção, representada pela regra segundo a qual deve deixar de ser acolhida a convenção que se revelar improfícua ou gerar inconsistências, seja justificável como mera "tomada de decisão". Despreocupado em determinar se as regras são utilizadas na ciência real, o convencionalismo metametodológico propõe a adoção das que pressupõe capazes de gerar resultados confiáveis. O convencionalismo precisa ter um substrato consequencialista para evitar a conclusão de que seu sistema de regras é, em tese, tão bom quanto qualquer outro. O enfrentamento do desafio de saber se um conjunto de convenções é profícuo à prática da ciência, se autoriza e veta acertadamente determinados tipos de conduta na pesquisa, envolve ir além do plano convencional. Popper se satisfaz em estabelecer analogias entre ciência e jogo:

Assim como o xadrez pode ser definido pelas regras que lhe são próprias, a ciência empírica pode ser definida por meio de suas regras metodológicas. No estabelecimento dessas regras podemos proceder sistematicamente. Primeiramente, uma regra suprema pode ser formulada para servir como uma espécie de norma para decidir sobre as regras remanescentes. Trata-se, portanto, de uma regra de tipo superior. É a regra que diz que as outras regras do procedimento científico devem ser elaboradas de tal forma que não protejam qualquer enunciado científico contra a falsificação. (POPPER, 1959, p. 54)

Com base na pretensa constatação de que inexistem traços que representem o que a ciência tem de essencial, o convencionalismo metametodológico precisa indicar o que pode lhe conferir sustentação normativa. Defrontado com a necessidade de enunciar uma Regra Maior, com poder para estipular como devem ser todas as outras regras, Popper também a concebe como mera convenção. Em teoria, um sistema de convenções pode ser rejeitado com base na alegação de que é desnecessariamente restritivo ou de que é inadequado às variadas práticas de pesquisa presentes nas diversas ciências ou até mesmo no interior de uma mesma ciência como ocorre nas disciplinas sociais. Caso se repute admissível a defesa de diferentes sistemas de regras concebidas como convenções, deixa de se poder atribuir o sucesso explicativo, preditivo ou instrumental da ciência à excelência da metodologia que emprega. Encaradas como conveniências, as convenções só se 
mostram passíveis de ser instrumentalmente avaliadas. Mesmo sendo determinado sistema de convenções escolhido por suas vantagens comparativas, pode, em tese, vir a perder o lugar para outro que desponte circunstancialmente superior. A escolha de convenções que não se mostrar indispensável à consecução do alvo mirado poderá ser sempre questionada. Está longe de ser fácil provar a superioridade - ao longo do tempo - de um sistema de convenções para diferentes casos e situações de pesquisa nas variadas e desniveladas ciências.

Admitindo-se que nenhum sistema de convenções exclui a adoção de outros, o desafio passa a ser o de fazer a escolha de um deles sem poder justificá-lo como um imperativo categórico ou hipotético da racionalidade. Além do mais, enfraquece a manifestação de preferência por um sistema de regras - contra alternativas - se nunca se justificar atribuir ao escolhido escopo e normatividade universais. O problema que deixa de ser enfrentado por Popper é o de como conciliar o convencionalismo metametodológico com um sistema de avaliação que emite juízos negativos peremptórios e rejeita sistemas metodológicos alternativos. Lakatos (1977, p. 106) indigita a dificuldade ao destacar que "o falsificacionismo metodológico de Popper é ao mesmo tempo convencionalista e falsificacionista".

Popper é de opinião que não há como julgar metodologias rivais - como o convencionalismo defendido entre outros por Poincaré e o racionalismo crítico - porque a única coisa que se pode fazer é tomar uma decisão conducente à adoção de uma e à desconsideração ou rejeição de outras. Para Popper, os valores embutidos nessas metodologias são tão fundamentais que nenhum argumento pode ser apresentado em prol da adoção de um valor em detrimento de outro sem que se tenha um envolvimento prévio com algum valor. No entanto, Popper nem sempre reitera tal concepção decisionista de metamétodo. Isto porque em obras posteriores a Logik der Forschung sugere a existência de maneiras de comparar metodologias rivais confrontando suas regras e valores discrepantes. O convencionalismo se defronta com o repto de justificar escolhas impermeáveis à acusação de que expressam preferências epistemológicas vinculadas a determinados ismos filosóficos. As convenções e valores da metodologia a ser empregada pela ciência precisam ser universalizáveis para que a ciência, à maneira de um jogo, se submeta sempre ao mesmo conjunto de regras e procedimentos.

Voltando as costas para a grande variedade das práticas de pesquisa nas ciências, principalmente nas sociais, o convencionalismo metametodológico popperiano adota posição "unicista" à luz da qual só há uma forma de se fazer (boa) ciência. Desse modo, promove a desqualificação de muitas práticas de pesquisa - convencionalmente estabelecidas - adotadas em ciências "imaturas" como as sociais. É questionável a autoridade do convencionalismo metametodológico para desqualificar, por meio de juízos metametodológicos taxativos, procedimentos propostos por outras filosofias da ciência tendo em vista que reduz escolhas a uma "questão de decisão". Cumprindo papel crucial nos diferentes tipos de convencionalismo, as decisões tomadas não têm ao seu lado a compulsão epistêmica com base na qual poderiam se impor às alteridades. No caso de inexistirem boas razões para desmerecer as alternativas, a preferência por determinadas convenções representaria um fato destacadamente social.

A concepção de Popper de que a ciência é una, empregadora de procedimentos convencionais invariantes, é incapaz de identificar as causas do crônico "subdesenvolvimento" explicativo das ciências sociais. É problemático o diagnóstico de que tal "subdesenvolvimento" seja fruto da resistência a adotar as convenções certas, uma vez que já se tentou, em termos metodológicos, praticamente de tudo nas disciplinas sociais. $\mathrm{O}$ convencionalismo metametodológico substitui a questão kantiana das condições cognitivas de possibilidade da ciência pela da funcionalidade da ciência como um jogo. Assim como um jogo é fruto das convenções que tornaram sua existência possível, as ciências deveriam deixar para trás a diversidade procedimental porque possuem uma só identidade, que é a que resulta das convenções adotadas.

Se em suas versões puramente "metodológicas" as avaliações científicas são convenções, que podem sempre ser formuladas como uma definição de ciência, como se pode criticar, indaga Lakatos (1981, p. 123), a definição? Se interpretada de modo nominalista, uma definição é, como destaca Lakatos, uma mera abreviação, uma sugestão terminológica, uma tautologia. E como se pode criticar uma tautologia? Citando Menger, para quem "definições são dogmas; apenas as conclusões extraídas delas podem nos proporcionar um novo insight", Popper (1959, p. 55) sustenta que "isso é verdadeiro da definição do conceito de 'ciência”". 
Entende Popper que a única razão para propor um critério de demarcação é que se mostre "frutífero" no sentido de que "um grande número de pontos pode ser clarificado e explicado com sua ajuda". Mas como pode, questiona Lakatos, "uma definição ter poder explicativo ou prover novos insights?" A resposta de Popper é pouco elucidativa em virtude de se limitar a invocar algo nebuloso como a intuição: "somente com base nas consequências de minha definição de ciência empírica, e das decisões metodológicas que dependem desta definição, o cientista será capaz de determinar em que extensão ela está em conformidade com sua ideia intuitiva da meta visada por seus esforços".

Na formação de seu critério de demarcação, Popper considera decisiva a necessidade de as teorias aspirantes à cientificidade terem a propriedade de ser falsificáveis. Ser suscetível de completa revisão, de refutação, pode ser visto como um atributo lógico-epistêmico constitutivo do ser da ciência. A questão é que a opção por buscar obsessivamente um contraexemplo é uma decisão tomada de modo convencional. Apresentando seu "critério de demarcação como uma proposta de um acordo ou de uma convenção", Popper (1959, p. 37) defende a posição geral de que as convenções podem ser criticadas discutindo-se sua 'conformidade' a algum propósito: "as opiniões com relação à conformidade da convenção podem ser diferentes; e uma discussão razoável sobre essas questões só é possível entre partes que tenham algum propósito em comum”. A conclusão de Popper é a de que "a escolha desse propósito deve, em última análise, ser uma questão de decisão, que vai além da argumentação racional". Na embasada e taxativa avaliação de Lakatos (1981, p. 123), "Popper nunca ofereceu uma teoria da crítica racional das convenções consistentes, uma vez que não formula a questão, e muito menos a responde, 'em que condições alguém renunciaria a seu critério de demarcação".

Diferentemente de Kuhn, Popper não pensa que um sistema diferente de normas ou valores metodológicos seja adotado quando ocorre uma radical mudança de teoria. O pressuposto de Popper é o de que as convenções metodológicas, certas, acabam mantidas por maior que tenha sido a amplitude da revolução científica. Sendo a ciência feita com base em regras que têm o estatuto de convenções, sendo tudo redutível a uma mera questão de decisão, a questão fundamental é determinar o que promove a escolha justificada de umas em detrimento de outras. Isto porque só seria desarrazoado perseverar com uma metodologia caso sua aplicação tivesse um histórico de resultados pouco confiáveis. Nas ciências sociais, insiste-se na defesa de um conjunto de procedimentos metodológicos alegando que seu emprego é indispensável para lidar com as especificidades de determinados objetos de estudo ou por propiciar, por exemplo, a obtenção de resultados qualitativos. Nesse caso, tenta-se justificar as regras do método com base em razões epistêmicas ou nas peculiaridades ontológicas do que é investigado.

Descrendo que haja influência da teoria, da sua substância explicativa, na escolha das convenções, Popper propõe que as preferidas sejam as que acredita terem escopo e aplicação universais. Sendo assim, as alterações metodológicas deixam de acompanhar, como pensa Kuhn, as mudanças ocorridas quando da substituição de determinados conteúdos teóricos por outros incomensuráveis. É discutível que o convencionalismo metametodológico per se - sem recurso a uma instância não convencional - possua legitimidade epistemológica para "condenar" as práticas de pesquisa que adotam convenções de tipo indutivista. Pensamos ser necessária uma legislação metodológica pretensões essencialistas, que se apresente como expressão da racionalidade científica, para tornar mandatório o emprego de um sistema de convenções e a colocação das alteridades no ostracismo.

Difícil conciliar as implicações "pluralistas" do convencionalismo metametodológico com uma lógica da pesquisa calcada na cogência do modus tollendo tollens. A articulação do convencional com o lógico é "tortuosa" porque Popper desqualifica como inatingível a comprovação da verdade bem como a atribuição de probabilidade às teorias. Além de defender de modo taxativo seu sistema de convenções, Popper condena de modo veemente os sistemas metodológicos alternativos ao seu. A introdução de convenções metodológicas vinculadas ao modelo hipotético-dedutivo de explicação desqualifica de modo peremptório o emprego de qualquer tipo de inferência indutiva na pesquisa científica. A avaliação que reputa epistemologicamente falhas as alteridades metodológicas transcende o domínio das decisões tomadas em âmbito puramente convencional. Tanto é assim que cada convenção metodológica requer o apoio último de uma Regra Suprema, que 
carecerá de poder deôntico caso se reduza a uma 'questão de decisão'. É questionável que o convencionalismo metametodológico confira autoridade e legitimidade epistemológicas para se estatuir que regras devem ser adotadas como também para afastar procedimentos alternativos vinculados, por exemplo, ao indutivismo ou bayesianismo.

É parcamente justificável a pretensão de absolutizar um sistema de convenções, e frágil a tentativa de indiretamente defendê-lo indigitando falhas nas alteridades. A decisão a favor de certas convenções deveria se escorar mais na demonstração das virtudes da escolhida do que na exibição dos defeitos das alternativas. Apesar de renunciar à busca de fundamentação estritamente epistêmica para as regras do método, o convencionalismo metametodológico torpedeia as alteridades lançando mão de veredictos como o que desaprova a indução por carecer de justificação racional. Daí a observação de Pandit (1991, p. 204) de que não há como "propor nem justificar regras metodológicas simplesmente aconselhando o rechaço ou a proibição do uso de possíveis alternativas a elas". Lastreado em argumentos forjados por Hume, Popper se dedicou a uma cruzada antiindutivista na qual a argumentação epistemológica é decisiva na defesa do banimento da indução e de sua substituição pelo modelo hipotético-dedutivo. É controverso que Popper tenha provado a dispensabilidade da indução bem como que tenha desenvolvido uma alternativa aplicável às várias e desniveladas ciências. Sem falar que seu próprio sistema metodológico promove o recurso tácito a inferências de tipo quase-indutivo quando, por exemplo, introduz o conceito de corroboração.

Lakatos (1981, p. 106) sublinha que se o convencionalista deseja conservar a ideia de que o crescimento da ciência "factual" tem alguma coisa a ver com a verdade objetiva, factual, deve conceber algum princípio metafísico a ser sobreposto às suas regras para o jogo da ciência. Se não o fizer, conclui Lakatos, não tem como escapar do ceticismo ou, pelo menos, de alguma forma radical de instrumentalismo:

Independentemente de qualquer lógica da descoberta, pode-se acreditar que o mundo exterior existe, que há leis naturais e que o jogo científico produz proposições que se aproximam cada vez mais da verdade; mas nada há de racional nessas crenças metafísicas, são meras crenças animais. Nada há na Logik der Forschung que leve o mais radical cético a dela discordar. (LAKATOS, 1974, p. 254)

Essa avaliação de Lakatos resulta de Popper advogar na Logik der Forschung não só que a metodologia e a epistemologia se devotam à proposição de convenções como também que a escolha de um conjunto de convenções em detrimento de alternativas não tem como ser feita de modo estritamente racional. É cabível pensar que o convencionalismo metametodológico está na origem da depreciação da metodologia e do relativismo que penetrou fundo na filosofia da ciência do século passado. Como aponta Laudan (1996, p. 125), "se a metodologia um dia ocupou lugar de destaque entre os filósofos da ciência, muitos hoje se mostram céticos quanto às suas perspectivas [...] Popper, em geral, trata as regras metodológicas como convenções, entre as quais nenhuma escolha racional pode ser feita". É elucidativa a constatação de Lakatos (1981, p. 123) de que "Popper em sua Logik Forschung nunca especifica um objetivo para o jogo da ciência que vá além do que está contido em suas regras; a tese de que o objetivo da ciência é a verdade aparece apenas em seus escritos a partir de 1957; tudo o que apregoa em sua Logik Forschung é que a busca da verdade pode ser uma motivação psicológica para os cientistas".

É difícil combinar o convencionalismo metametodológico, que deveria abarcar o Princípio da Tolerância, com a forma com que Popper ataca as modalidades de procedimentos metodológicos diferentes dos que recomenda. É discutível que se justifique tirar dos indutivistas o direito de escolher suas convenções. Mesmo porque podem alegar que a despeito da precariedade, em termos lógicos, das inferências ampliativas, é possível empregá-las de modo metodologicamente responsável. Podem, além do mais, sustentar que determinados tipos de objeto se mostram mais consentâneos com a construção de explicações de tipo indutivo-probabilístico. Algo similar pode se alegado por um confirmacionista que atribua grande importância à evidência positiva mesmo reconhecendo que só o contraexemplo pode levar a uma avaliação definitiva da hipótese ou teoria. Contra essas ponderações Popper pressupõe que convenções diferentes das que propugna são inócuas, ineptas 
ou geradoras de inconsistências. O problema é que rejeitar a concessão de universalidade "deontológica" às regras para concebê-las como convenções envolve reconhecer que alternativas não só são cogitáveis como são insuscetíveis de rechaço a priori. Está longe de ter sido provado que com o "programa" empirista lógico deixa de ser viável praticar (de modo apropriado) o jogo da ciência:

\begin{abstract}
Podemos, por exemplo, considerar e comparar dois sistemas diferentes de regras metodológicas; um com e outro sem um princípio de indução. Em seguida, examinamos se tal princípio, uma vez introduzido, pode ser aplicado sem dar origem a inconsistências; se nos ajuda e se realmente precisamos dele. É este tipo de investigação que me leva a dispensar o princípio da indução: não porque tal princípio nunca seja de fato usado na ciência, mas porque, acredito, que não é necessário. Não nos ajuda e até dá origem a inconsistências. (POPPER, 1959, pp. 52-3)
\end{abstract}

A decretação da dispensabilidade da indução e de sua falta de serventia, ou sua condenação pelo risco de incorrer na falácia da distribuição ilícita, demanda o recurso a princípios lógicos que, se nada mais forem que convenções, também podem, ao menos em teoria, ser substituídos por quaisquer outros. Nesse caso, as inconsistências poderiam ser ignoradas em nome da adoção de outro sistema de regras baseado na perseguição de outro fim. Popper enfrenta o desafio de harmonizar sua visão das regras metodológicas como convenções com a postura que o leva a fazer avaliações epistemológicas peremptórias das alteridades às convenções que defende. Da condenação inapelável da indução, Popper extrai consequências normativas que extrapolam o universo das convenções. Contrapondo-se ao empirismo lógico, Popper se coloca contra a vinculação da reconstrução racional da ciência à da linguagem da ciência sem lograr comprovar que a troca da linguagem por jogo seja mais elucidativa. Tendo a preferência por determinadas convenções de ser justificada em termos consequencialistas, isso quer dizer que nada mais são que imperativos hipotéticos. Procurando se afastar do deontologismo e do consequencialismo, Popper (1959, p. 63) defende a tese ousada de que "a questão de se as leis da ciência são estrita ou numericamente universais não pode ser resolvida por argumento; que é uma dessas questões que só podem ser resolvidas por concordância ou convenção". Ao renunciar a recorrer a estipulações epistêmicas concebidas como imperativos categóricos ou hipotéticos da racionalidade, essa visão se defronta com o desafio de justificar de modo estritamente convencional a opção por uma das posições conflitantes.

\title{
2. CIÊNCIA: REGRAS CONSTITUTIVAS OU REGULATÓRIAS?
}

Com seu convencionalismo metametodológico, Popper abriu caminho para metaciências que passaram a dar destaque à dimensão histórico-social, ou funcional-institucional, da atividade de pesquisa. A versão "socializada" do convencionalismo metametodológico leva à defesa da ideia de que cada comunidade, inclusive a científica, pode adotar as regras que considerar apropriadas e fecundas, de tal modo que fica inviabilizada a tradicional pretensão de submeter todos os resultados científicos aos mesmos e atemporais padrões de avaliação. O Programa Forte em sociologia da ciência se considera caudatário do convencionalismo metametodológico:

Um sociólogo pode concordar com a insistência de Popper de que o que torna o conhecimento científico não é a verdade de suas conclusões, mas as regras procedimentais, os padrões e as convenções intelectuais aos quais ele se conforma. Dizer que o conhecimento é uma questão de padrões e convenções é apenas dizer que é uma questão de normas. Uma teoria convencionalista do conhecimento como a de Popper pode ser vista como o esqueleto abstrato de uma explicação sociológica mais realista do conhecimento. (BLOOR, 1991, p. 159) 
Lakatos (1977, p. 108) também sublinha que "o falsificacionista metodológico reconhece, por uma questão de fato, que essas convenções são institucionalizadas e endossadas pela comunidade científica; a lista dos falsificadores 'aceitos' é fornecida pelo veredicto dos cientistas experimentais". O relativista, tal qual descrito por Laudan (1990, p. 33), aquiesce que "os testes são projetados de acordo com certas regras ou métodos", mas sem deixar de ressalvar que em virtude de "não nos chegarem do céu" nada mais "são convenções socialmente sancionadas, carentes de força probatória". Se o sociólogo, o físico, o químico, o psicólogo, o arqueólogo, o politólogo etc. adotam variáveis convenções e as justificam com base na alegação de que são as que se mostram apropriadas ao que investigam, deixa de se justificar falar de ciência no singular. Inexistindo máximas obrigatórias de conduta na pesquisa, procedimentos universalmente proficientes, imperativos categóricos estatuídos pela razão, então vários sistemas de regras - socialmente induzidos - podem ser adotados.

É fato que uma regra convencional tem de ser realmente seguida pela maioria dos membros de um grupo a fim de existir e subsistir. Só regras convencionais efetivamente seguidas dão origem a uma prática social. Convenções que ficam na mente ou no papel, que não são acatadas, carecem de efetividade na moldagem das condutas. As razões para seguir regras não têm como ser epistemicamente fundamentadas em virtude de as convenções, para existirem, dependerem primariamente de fatos como o de serem ampla e reiteradamente seguidas pelos membros do grupo. Sendo fundamentalmente sociais os fatores que levam os cientistas a agirem em conformidade com algumas convenções, as razões epistêmicas são coadjuvantes. A função cumprida pelas convenções para viabilizar a existência de certas práticas na ciência seria operacionalmente similar da que desponta necessária para regular as interações sociais em geral. Nesse caso, as convenções em geral têm o condão de criar práticas e padrões comportamentais independentemente das razões invocáveis para justificar sua existência. Como destaca Hart (1994, p. 255), a efetividade de uma convenção depende de ser efetivamente seguida: "regras são práticas sociais convencionais se a conformidade geral de um grupo a elas é parte das razões que seus membros individuais têm para aceitá-las"

Em obra posterior a Logik der Forschung, Popper (1986, p. 67) estabelece clara distinção entre "as leis normativas impostas pelo homem, com base em decisões ou convenções, e as regularidades naturais que estão além de seu poder". Indo contra a visão de que as normas, por serem convencionais são 'meramente arbitrárias', Popper (1986, p. 61) assevera que "o dualismo crítico se limita a defender que normas e leis normativas podem ser feitas e alteradas pelo homem, mais especialmente por uma decisão ou convenção de observá-las ou alterá-las; e que o homem é, portanto, o responsável moral por elas", de tal modo que "é de nossa alçada melhorá-las tanto quanto pudermos se as consideramos objetáveis". Estando a substituição prevista, a ponto de inexistir justificativa para absolutizar convenções, Popper ressalta que "descrever as normas como convencionais não implica que sejam arbitrárias ou que um conjunto de leis normativas será equivalente a qualquer outro". Nesse caso, o desafio consiste em determinar o que as diferencia em termos funcionais e operacionais para que se possam fazer escolhas justificadas.

O convencionalismo metametodológico deveria se considerar incompatível com a regulamentação monopolista e mais harmonizável com o "indiferentismo" com base no qual há sempre a possibilidade de diferentes constelações de convenção despontarem contextualmente defensáveis. Não sendo arbitrárias, as convenções precisam ser bem escolhidas para que possam ser reiteradamente usadas na geração de resultados confiáveis. Difícil provar que algumas são melhores, ou que tornam possível praticar o jogo da ciência, sem recorrer às razões epistêmicas similares às tradicionalmente elencadas pelos essencialistas. Ao advogar que cabe aperfeiçoar, tanto quanto possível, as convenções, Popper enfrenta a dificuldade de indicar como isso pode ser feito de modo consensual. A rejeição da tese de que um conjunto de convenções tem tanta serventia quanto qualquer outro precisa propor critérios que respaldem a preferência. Visto que as razões invocadas em apoio a um sistema de convenções não são nem demonstrativas nem empíricas, resulta difícil justificá-lo e até mesmo propor aprimorá-lo sem recorrer tacitamente a um modelo normativo. Para evitar ficar refém da arbitrariedade do que é convencionalmente estatuído, Popper advoga que algumas leis podem ser melhores que outras e acredita ser viável "comparar as leis normativas existentes (ou as instituições sociais) com certas normas-padrão que decidimos serem dignas de adoção". Difícil hierarquizar as convenções sem recorrer a um plano supraconvencional, uma vez que esses padrões, como o próprio Popper reconhece, são 
de nossa autoria "no sentido de que nossa decisão em favor deles é uma decisão nossa e só nós carregamos a responsabilidade de adotá-los". Popper acredita que na ciência, assim como na sociedade, é fundamental escolher o sistema certo de convenções para que seus 'jogos' sejam praticados da melhor maneira. $\mathrm{O}$ desafio é definir convencionalmente o que é certo em um tipo de atividade como a científica que se pretende regida por escolhas racionalmente justificadas.

\subsection{SERÃO AS REGRAS DO MÉTODO CONSTITUTIVAS?}

Visto que convenções podem ser preteridas em prol de outras, a comparação da ciência com jogo visa a evitar que faltem imperativos normativos em apoio à opção feita. Mesmo porque o desejo de praticar determinado jogo torna obrigatório seguir suas regras. O problema é que as regras do método precisam ser constitutivas, como o são as de jogos como o xadrez, para que se justifique estabelecer analogias funcionais entre ciência e jogo. Inexistindo convenções que consensualmente despontem como condição de possibilidade para se fazer (boa) ciência, todas despontam intercambiáveis. Se as convenções forem aferidas em termos de eficácia instrumental ou proficiência heurística, é de secundária importância distingui-las das regras do método tradicional. Caso a aplicabilidade das convenções seja contextualmente determinada, uma resposta possível é o anything goes feyerabendiano.

É necessário que as regras do método passem a ser reputadas funcionalmente equivalentes às dos jogos para que se justifique encarar a ciência e o xadrez como submetidos a um mesmo tipo de normatividade. Tendo em vista que cada jogo se define pelas regras que adota, a analogia entre ciência e jogo permite pensar que às práticas de pesquisa pode ser proposta como indispensável determinada constelação de convenções. Na comparação da ciência com jogo, Popper (1959, p. 54) estabelece analogias genéricas: "assim como o xadrez pode ser definido pelas regras que lhe são próprias, a ciência empírica pode ser definida por meio de suas regras metodológicas". Popper chega a advogar que as regras metodológicas diferem das regras da lógica pura da mesma maneira que as regras do xadrez:

Tendo presente que as regras da lógica pura regem as transformações de fórmulas linguísticas, o resultado de uma investigação das regras do xadrez poderia talvez se chamar 'A Lógica do Xadrez', mas dificilmente 'Lógica' pura e simples. (De modo similar, o resultado de uma investigação das regras do jogo da ciência - ou seja, da descoberta cientifica - pode ser intitulado 'A Lógica da Descoberta Cientifica'). (POPPER, 1959, p. 53)

Com o objetivo de mostrar ser inapropriado colocar uma investigação do método no mesmo nível de outra puramente lógica, Popper (1959, p. 53) dá dois exemplos simples de regras metodológicas. Pouco mais que um truísmo, uma das regras estatui: “o jogo da ciência é, em princípio, sem fim, e aquele que um dia decidir que os enunciados científicos não requerem testes ulteriores, ou que podem ser considerados definitivamente verificados, se retira do jogo". A outra estabelece que "uma vez que uma hipótese tenha sido proposta e testada, e tenha provado seus méritos, não se está autorizado a abandoná-la sem uma 'boa razão'” A 'boa razão' pode ser, por exemplo, a substituição da hipótese por outra melhor testável; ou a falsificação de uma das consequências da hipótese. Estes dois exemplos mostram com que se parecem as regras metodológicas, muito diferentes das geralmente chamadas de 'lógicas'. Embora a lógica possa estabelecer, segundo Popper, critérios para decidir se um enunciado é testável, não lhe concerne certamente a questão de se alguém se esforçará para testá-lo.

Para avaliar a proficuidade e o embasamento da comparação da ciência com jogo, acreditamos ser profícuo recorrer à distinção de Searle (1969, p. 33-4) entre regras constitutivas e regulatórias. Quando regulam uma atividade preexistente, formas de comportamento antecedentemente existentes, caso das regras de etiqueta ou de boas maneiras, são chamadas de regulatórias. Sendo assim, guiam o comportamento prescrevendo ou proscrevendo determinados tipos de ação. Já as regras constitutivas não só regulam como criam ou definem novas formas de comportamento, isto é, constituem uma atividade cuja existência é logicamente dependente 
das regras. As regras do futebol ou do xadrez não se limitam a regulá-los, tornam possível jogá-los. Em suma, há regras que "criam" realidades, sem deixar de regulá-las, e regras que apenas regulamentam o que já existe. Searle (1964, p. 55) sustenta que "regras regulatórias regulam atividades cuja existência é independente das regras, ao passo que as constitutivas constituem (e também regulam) formas de atividade cuja existência é logicamente dependente das regras; as instituições [...] são sistemas de regras constitutivas. As instituições do casamento, do dinheiro e das promessas são como as instituições do baseball ou xadrez no sentido de que são sistemas de regras constitutivas ou convenções".

Para se avaliar em que medida se justifica comparar a ciência a jogo, dando às regras do método o estatuto de convenções, é crucial identificar que tipo de instrução deve ser seguido para que se torne possível praticar um jogo como o xadrez ao qual Popper faz menção especial. Só assim se pode determinar se os procedimentos metodológicos na ciência cumprem função análoga à das regras dos jogos. Caso as regras do método sejam, em termos funcionais, pouco ou nada distinguíveis das regras de um jogo, fica difícil justificar o valor normativo especial que tem se tendido a atribuir aos cânones do método apresentando-os como uma espécie de "Legislação da Razão".

Quase duas décadas antes de Popper comparar a ciência ao xadrez, Saussure (1995, p. 43) fizera o mesmo com a língua encarando-a como "um sistema que só conhece sua própria ordem". Entende Saussure que "uma comparação com o jogo de xadrez ensejará compreendê-la melhor". O que o eminente linguista destaca é muito elucidativo: "nesse jogo, é relativamente fácil distinguir o que é externo do que é interno: o fato de ter passado da Pérsia para a Europa é de ordem externa; interno, ao contrário, é tudo que diz respeito ao sistema e às regras":

Se eu substituir as peças de madeira por peças de marfim, a mudança é indiferente para o sistema, mas se eu diminuir ou aumentar o número de peças, a troca afetará profundamente a "gramática" do jogo [...] Desse modo, em cada caso se colocará a questão da natureza do fenômeno e, para resolvê-la, será observada a seguinte regra: é interno tudo o que, em algum grau, altera o sistema. (SAUSSURE, 1995, p. 43)

A comparação feita por Saussure entre língua e xadrez é mais esclarecedora que a estabelecida por Popper entre ciência e xadrez porque chama a atenção para as regras que, sendo constitutivas de um sistema, não têm como ser alteradas sem que isso afete a identidade do sistema. O que é interno define a natureza de alguma coisa, o que é externo é acidente histórico. Poincaré (1968, p. 45) aponta para uma dessemelhança importante entre ciência e xadrez: “a teoria do jogo de xadrez não poderá jamais se tornar uma ciência, já que as diferentes jogadas de uma mesma partida não se assemelham”. Ademais, os gambitos da ciência não seguem rigidamente uma sequência determinada por uma estrita obediência aos imperativos estatuídos por um método reconhecidamente universal. Jogos se desenrolam por meio de partidas independentes, ao passo que na ciência é manifesta a interdependência entre o antes e o depois mesmo quando ocorrem grandes mudanças de teoria. O "campeonato" da ciência se desenrola como uma grande partida, de tal modo que só se passa para outra quando se verifica algum tipo de descontinuidade similar à mudança de paradigma.

Acreditamos que a justificação da comparação da ciência com jogo depende da resposta que se pode dar à questão de se a ciência, à semelhança dos jogos, é praticada com base em regras constitutivas. A tentativa de comparação, de estabelecimento de analogias normativo-funcionais, se mostrará pouco elucidativa se a ciência, à diferença de um jogo, não for regida por regras constitutivas. Caso tivessem função do mesmo tipo da das regras dos jogos, as do método confeririam uma identidade essencial à ciência e definiriam modos inevitáveis e obrigatórios de praticá-la. Para que se justifique falar de "inevitabilidade metodológica" é preciso que a existência da ciência, e de suas práticas, resulte da adoção de regras constitutivas. As tantas teorias do método - arroladas por Laudan (1968, p. 1-63) - evidenciam que são desprovidas de natureza constitutiva as regras às quais se tem conferido a missão - ainda que de forma idealizada - de conduzir, nortear e avaliar os resultados da pesquisa científica. Contra a visão de que são constitutivas as regras que regem a pesquisa científica há a realidade da grande variedade de procedimentos encontráveis nas diferentes e desniveladas ciências. 
Encarar a ciência como um jogo implica pensá-la submetida a um tipo específico de regra sem o qual não tem como ser praticada. Sendo criações resultantes da introdução de determinadas normas, alguns tipos de entidade só existem enquanto as regras forem consensualmente seguidas. As regras constitutivas se distinguem por terem viabilizado práticas que conferem identidade a alguma coisa. Se as regras empregadas na ciência têm a mesma natureza das que constituem um jogo, das que rigidamente definem os modos de praticá-lo, então deixam de admitir alternativas mesmo tendo caráter convencional. Para evitar a proliferação decorrente da existência de diferentes conjuntos admissíveis de convenção, Popper procura demonstrar que a ciência tem de ser tão rigidamente regrada quanto um jogo. O problema é que se as regras do método possuem natureza constitutiva, fica sem explicação a querela endêmica em torno de como a ciência é - deve ser - feita. Como nos jogos, as regras do método dar margem apenas às escolhas das jogadas que, dentre as permissíveis, variam de acordo com o talento e a inventividade dos jogadores. Fossem como as que ensejam a criação (e a prática) de um jogo, as normas metodológicas não fomentariam o interminável Methodenstreit, uma vez que seriam universalmente reconhecidas e empregadas em virtude de só com elas se poder fazer ciência da mesma forma que só acatando as regras do xadrez se logra jogá-lo.

Para que se justifique postular semelhanças de família - como as caracteriza Wittgenstein $(1968, \S 67)$ entre ciência e jogo, é crucial que ambas as atividades estejam submetidas ao tipo constitutivo de regra. Para ficar comprovado que a ciência se submete a um tipo de sistema normativo similar ao de um jogo é necessário evidenciar que aquilo que a torna possível define permanentemente suas práticas. Não sendo constitutivas as regras seguidas nas ciências pouco têm a ver com as que criam e regulamentam os jogos. A sustentação da proposta de se comparar funcional e normativamente ciência e jogo depende de se constatar que são as regras do método a tornar possível a existência da ciência.

O convencionalismo metametodológico de Popper não renuncia a julgar (inadequadas) as convenções ou regras para a prática de pesquisa propostas, por exemplo, pelo holismo e o historicismo. Os veredictos popperianos precisam se basear no pressuposto de que as regras vinculadas ao refutacionismo podem reivindicar o estatuto de constitutivas. Consideradas indispensáveis para se organizar e regular a atividade de pesquisa bem conduzida, as convenções propostas por Popper nunca se provaram constitutivas, de tal modo que desponta injustificável decretar que sem elas não se consegue fazer (boa) ciência. É problemática a desqualificação de outros caminhos metodológicos se o convencionalismo metametodológico se mostrar incapaz de dissolver o problema referente às boas razões que precisam ser apresentadas, à parte conveniências e preferências, para se preferir justificadamente um sistema metodológico a outro em certas modalidades de pesquisa. Sem conseguir diminuir a controvérsia endêmica na filosofia da ciência em torno da questão do método, o convencionalismo metametodológico se afasta ainda mais do consenso sobre o tipo de norma que deve reger uma atividade de pesquisa para que obtenha estatuto cientifico.

Escolher uma constelação de convenções exige enfrentar o desafio de legitimá-la por seus méritos aferidores superiores ou pelas vantagens comparativas que tem em comparação com alternativas. Fazer isso envolve recorrer a um plano supraconvencional. Caso a ciência fosse funcional e normativamente similar ao xadrez seria dispensável problematizar com base em que são escolhidas as regras que devem conduzir suas operações. Fossem as regras método do mesmo tipo das do xadrez, a atividade de pesquisa se submeteria universalmente a procedimentos rígidos, de tal modo que inexistiria a controvérsia metodológica endêmica que atravessa a história das ciências, em particular a das sociais. Mesmo que guiados por meras convenções, os passos dos cientistas seriam dados como se estivessem em conformidade com imperativos categóricos da racionalidade. Diferentemente do que pensa Kuhn, os procedimentos predeterminariam os passos sem qualquer dependência à variabilidade dos conteúdos tratados. Poderia haver variável proficiência e criatividade na ars inveniendi, como há nas performances dos jogadores, mas não na ars probandi em virtude de as regras, nesse caso, definirem prévia e peremptoriamente o que está o cientista autorizado a fazer para validar seus resultados.

A regra popperiana segundo a qual o pesquisador deve obsessivamente buscar refutar, de todos os modos possíveis, suas hipóteses, e não confirmá-las, por poucos cientistas é acatada e por poucos metodólogos é defendida. Se fosse constitutiva, seria cogente e despontaria como precondição para fazer ciência. Tendo o 
estatuto de convenções, sendo necessário admitir a existência de alternativas, as regras escolhidas não têm como postular monopólio legislativo. Apesar de procurar demonstrar que certas convenções necessitam ser seguidas para se conferir caráter científico à pesquisa, Popper em momento algum oferece a comprovação de que as regras do método que propõe são constitutivas, ou seja, condição de possibilidade para se fazer ciência. Supondo que para as convenções adotadas existam alternativas cogitáveis, a decisão a favor de umas, em detrimento de outras, acaba tendo de ser feita com base em critérios que encontram dificuldades para se legitimar, eles mesmos, como meramente convencionais. Ademais, é problemático julgar e condenar alteridades metodológicas, como faz Popper com o holismo as ciências sociais, se as regras do método são convenções desprovidas do poder "deôntico" dos imperativos categóricos da racionalidade.

Para que se justifique proclamar que as convenções escolhidas são superiores é imperioso provar que são epistemicamente mais consistentes ou instrumentalmente mais eficazes. O irrestrito convencionalismo metametodológico leva à consequência de que mais de um conjunto de convenções pode ser proposto e colocado em prática. Pode-se até pensar em constelações de convenções incompatíveis umas com as outras. Nesse caso, são várias as dificuldades para se estabelecerem méritos relativos. Ademais, Pandit (1991, p. 121) tem razão quando argumenta que "dadas duas teorias rivais $\mathrm{T}^{1}$ e $\mathrm{T}^{2}$ em um mesmo domínio, o convencionalismo metametodológico, como o entende Popper, implica, mesmo sem o pretender, que podem inexistir boas razões para se preferir $\mathrm{T}^{2}$ a $\mathrm{T}^{1}$. Mesmo porque cada uma pode ser uma teoria boa e aceitável à luz de um conjunto de convenções metodológicas, mas inaceitável à luz de outro". As ciências sociais exemplificam de modo exemplar os "impasses" que podem se formar entre resultantes "justificados" à luz de diferentes sistemas de convenção.

Ao comparar a ciência ao xadrez, pressupondo que as regras do método sejam constitutivas, Popper torna desnecessário derivar o chamado método científico do acompanhamento da ciência real que, com isso, deixa de poder arbitrar o que se propala sobre ela. Se as regras do método fossem constitutivas, se tivessem criado a ciência, se justificaria qualificar de ineptas algumas técnicas de pesquisa usadas em ciências marcadas por profundas cisões internas. O desenvolvimento das ciências seria desigual apenas em virtude da complexidade de seus objetos de estudo. Sendo as regras condição de possibilidade para um jogo existir, se as do método científico também fossem constitutivas não precisariam ser epistemologicamente formuladas e fundamentadas. Bastaria identificá-las em operação, de tal modo que inexistiria obstáculo à sua pronta e consensual aceitação e utilização. Uma reflexão sobre a fundamentação das regras do método possuiria relevância exclusivamente epistemológica, mas deixaria de se justificar qualquer pretensão do filósofo de prescritivamente modificá-las ou substituí-las.

A variedade e a diversidade dos procedimentos que podem ser encontrados em uso nas diferentes ciências deixam claro que a funcionalidade delas não está submetida a regras constitutivas. Caso estivessem, seria defensável a teoria da unidade do método e inútil a pregação naturalista que recomenda que as ciências sociais imitem as naturais. As controvérsias endêmicas entre psicólogos e entre sociólogos, no preciso diagnóstico de Kuhn (1970, p. 58), sequer viriam a existir se as regras do método, como as do xadrez, formassem um hard core normativo-funcional universalmente seguido e mantido inalterado. Um método com o poder de dar origem à ciência teria de ser formado por regras vistas por todos os pesquisadores como as únicas aceitáveis. Pressupondo serem as regras constitutivas, o convencionalismo metametodológico não cogita da possibilidade de variarem de acordo com o evolver das práticas científicas. O embate entre sistemas rivais de convenção só ocorreria se tivessem natureza regulatória.

Quando busca especificar o que viabiliza a pesquisa, Popper deixa claro acreditar que a ciência, assim como xadrez, se define por suas regras. Fosse esse o caso, inexistiria a recalcitrante diaphonia metametodológica, a insuperável discussão em torno da natureza das regras e dos procedimentos a empregar para se fazer ciência. É inconteste que cada jogo requer um e apenas um conjunto de regras, mas é questionável que exista $a$ ciência e que possa ser praticada com base em um único sistema normativo que, possuidor de natureza constitutiva, se imporia "automaticamente" em todos os domínios da pesquisa científica. A longeva polêmica em torno da questão do método evidencia que o que torna possível a atividade qualificável de científica não 
é previamente estabelecido pelas regras nem é ontologicamente construído por elas. Enquanto as regras do xadrez são reconhecidas como condição de possibilidade para a existência e a prática do jogo, as atribuídas à ciência são variavelmente propostas por cientistas e filósofos.

O fato de a comparação da ciência com jogo poder ser questionada tanto em termos operacionais/ funcionais quanto normativos leva Pandit (1991, p. 122) a exagerar quando sustenta que "a suposição básica de Popper, embora tácita, que assimila ciência a jogos não se mostra capaz de suportar o escrutínio crítico". Não discordamos do critério trivial de Pandit à luz do qual só é possível "decidir se uma atividade é ou não um jogo averiguando se tem ou não propriedades similares às do jogo independentemente de se jogo é entendido no sentido comum ou teórico". No entanto, merece ser discutida a tese forte de Pandit de que "não podemos dizer da ciência empírica que é um jogo em qualquer dos dois sentidos". Sólida se nos afigura a argumentação de Pandit segundo a qual "as atividades/situações do tipo chamado 'jogo' têm um caráter muito mais simples e são muito mais rigidamente governadas por regras em comparação com as situações-problema características da ciência”.

Em apoio à tese de que regras metodológicas são muito diferentes das usualmente chamadas de lógicas, Popper argumenta que a despeito de a lógica poder estatuir os critérios com base nos quais é possível decidir se um enunciado é testável, foge de sua alçada a questão de se o pesquisador se empenhará em testá-lo. Tratando-se de uma questão de decisão, deve ser localizada no campo da pragmática. É trivial a constatação de que nenhum sistema de normas tem per se poder para assegurar seu acatamento. Só que no caso de atividades que requeiram regras constitutivas, a ausência destas impede a existência daquelas, e não apenas a execução de certas ações do modo apropriado.

Sabemos, à luz da história da ciência, que apesar do poder logicamente decisivo do contraexemplo, toda uma comunidade de pesquisadores pode ser leniente com a evidência desfavorável a uma teoria. Popper entende que aqueles que adotam esse tipo de postura renunciam a fazer (boa) ciência. A necessidade de conciliar convencionalismo metametodológico com a imperiosidade lógica do refutacionismo leva Popper a propor uma regra suprema - o que gera a formação de uma hierarquia normativa entre as regras - com poder para impor a observância das demais. Para erigir em suprema a regra da falsificabilidade, é questionável que baste defendê-la como uma mera convenção, uma vez que, tratada como puramente convencional, pode deixar de ser seguida em nome da adoção de alternativa. Nesse caso, a ciência não precisaria ter a identidade que Popper lhe atribui. Se a regra reputada suprema não for constitutiva desaparece a necessidade de acatá-la como condição de possibilidade para se fazer ciência, e desponta problemático comparar a ciência a jogo.

Se as regras do método fossem constitutivas, formuladas previamente e justificadas independentemente de como a ciência tem sido feita, as polêmicas de Popper com os verificacionistas, os probabilistas, os justificacionistas e os indutivistas teriam de ser vistas como se desenrolando no terreno estrito da epistemologia e não em um domínio que, para merecer ser chamado de filosofia da ciência, precisa ser uma reconstrução filosófica estribada na ciência real. Se ninguém discute a funcionalidade e a fundamentação das regras do xadrez é por serem constitutivas e se mostrarem impermeáveis às variações das jogadas e das partidas. Já o grau de dependência das regras aos "conteúdos" na ciência é matéria controversa. Enquanto as regras do xadrez não têm a ambição de ensinar a jogá-lo bem, as do método comumente são apresentadas como sendo indispensáveis para se fazer ciência. É discutível que, à maneira do que ocorre no xadrez, na ciência só a inventividade das jogadas varie, não os tipos de regra admissíveis ao longo do tempo, e que os fatores sociais em nada afetem os modos de conduzir e aferir a pesquisa.

Se em processos específicos de pesquisa, regras como a da refutação estão sujeitas a ser ignoradas ou relativizadas - conforme argumentam, entre outros, Kuhn, Lakatos e Feyerabend - isso implica que a efetividade de certas convenções é fruto de necessidades ou conveniências contextuais. Por esse motivo, Kuhn fala de anomalia e não de evidência contrária, sem deixar de ressaltar que todo paradigma já nasce com algum "defeito". Sendo esse o caso, as convenções que organizam o funcionamento procedimental da ciência não cumprem a mesma função das regras constitutivas dos jogos. Caso as mudanças de teoria acarretem, como advoga Kuhn, descontinuidades que impactam até as regras do método desponta nítida a diferença com os 
jogos cujos resultados não estão sujeitos a revisões, complementações e anulações desde que as regras tenham sido respeitadas. Em um sistema aberto como o científico, o resultado de ontem é passível de ser completado e (re)avaliado à luz de novas evidências.

Mesmo se desprovidas de poder deôntico, as regras dos jogos são consensualmente adotadas e universalmente seguidas por serem ontológica e funcionalmente inseparáveis das práticas a que dão origem. Carentes da compulsão intrínseca dos imperativos categóricos da racionalidade, as regras constitutivas não podem deixar de ser respeitadas por aqueles que desejem praticar as atividades a que dão origem. Podendo ser praticados com mais ou menos destreza, inteligência, criatividade etc., os jogos são disputados por meio da realização de partidas independentes, cujo desenrolar e os resultados não dependem dos de outras partidas. Por mais que se coloque em dúvida a constância do progresso cumulativo, por mais que a preservação dos resultados precedentemente obtidos seja parcial quando das grandes mudanças teóricas, a dependência às conquistas anteriores é um dos traços distintivos da atividade científica. Tal característica está ausente dos jogos.

Popper (1959, p. 54) se vê diante da necessidade de atribuir uma tácita normatividade deôntica às convenções quando advoga a imperiosidade de uma "regra suprema formulada com o propósito de ser uma espécie de norma capaz de definir a aplicação das demais regras". Desnecessária para a boa prática dos jogos, a metarregra estipula que "as outras regras da atividade científica de pesquisa devem ser projetadas de tal modo a não proteger da falsificação qualquer enunciado da ciência". A metarregra parece operar como se fosse uma espécie de "axioma" metodológico com força normativa para cumprir a função precípua de respaldar a adoção de uma constelação de convenções em detrimento de alternativas. Caracterizando como empírico "um método que exclui precisamente esses modos de evitar a falsificação [...] logicamente possíveis", Popper (1959, p. 42) sublinha que "o que caracteriza o método empírico é sua maneira de expor à falsificação, de todos os modos concebíveis, o sistema a ser testado". A regra de ouro define mais o que não se deve fazer: ignorar o contraexemplo ou "absorvê-lo" artificialmente por meio do lançamento de hipóteses ad hoc. Cabe indagar até que ponto é justificável encarar a regra áurea como mera convenção e se, portadora desse estatuto, logra ser funcional e operacionalmente cogente a ponto de definir os cursos das pesquisas científicas.

Se o "mandamento supremo" exige que as regras que dirigem e controlam a atividade de pesquisa tenham um teor normativo-epistêmico que não proteja da falsificação uma hipótese com aspirações a ser científica, então a ciência, à diferença do xadrez, demanda metarregras. Para se evitar uma eventual regressão ao infinito, a metarregra que condena a desconsideração do contraexemplo precisa se estribar na constatação de que a evidência negativa é peremptória e a positiva, não. Visto que pode ser uma questão de decisão nada fazer para salvar uma teoria contra a qual despontou um falsificador real, emerge a necessidade de a decisão ser arrimada na pressuposição absoluta de que a única avaliação efetiva de uma teoria se dá pela detecção de evidência contrária a ela.

Se as regras do método científico fossem constitutivas, não haveria necessidade da Regra das regras. O xeque-mate, uma das regras constitutivas do xadrez, se impõe sem que seja necessário discutir sua adoção e muito menos sua fundamentação: simplesmente é indispensável para que exista tal jogo. Contudo, é questionável que seja condição de possibilidade para a existência da ciência a regra segundo a qual cumpre priorizar a busca da evidência adversa. $\mathrm{O}$ mesmo se pode dizer da regra que estipula que o acúmulo de evidência positiva nunca deve ser encarado como equivalendo à confirmação (gradual e crescente) de uma teoria capaz de definir sua probabilidade.

Apresentando seu "critério de demarcação como uma proposta de um acordo ou convenção", Popper (1959, p. 37) acredita que as convenções podem ser criticadas discutindo-se sua 'conformidade' a algum propósito: "as opiniões com relação à conformidade da convenção podem ser diferentes; e uma discussão razoável sobre essas questões só é possível entre partes que tenham algum propósito em comum”. A conclusão de Popper é a de que "a escolha desse propósito deve, em última análise, ser uma questão de decisão, que vai além da argumentação racional". Na embasada e taxativa avaliação de Lakatos (1981, p. 123), "Popper nunca ofereceu uma teoria da crítica racional das convenções consistentes, já que não enfrenta, e menos ainda responde, a questão: 'em que condições alguém renunciaria a seu critério de demarcação". Concordamos com a tese de Lakatos 
(1981, p. 122) segundo a qual esses jogos científicos se mostram carentes de qualquer relevância epistemológica genuína a menos que a eles se sobreponha algum tipo de princípio metafísico (se se quiser, "indutivo") que estabeleça que o jogo, conforme especificado pela metodologia, nos dá a melhor chance de nos aproximarmos da Verdade. Sem um princípio metafisico do gênero não há como fazer com que puras convenções, similares às de um jogo, gerem conjecturas falíveis com potencial explicativo. Sem tal princípio se pode dizer que o jogo científico é como qualquer outro. O problema bem destacado por Lakatos (1981, p. 123) é que

Popper em sua Logik Forschung nunca especifica um objetivo para o jogo da ciência que vá além do que está contido em suas regras; a tese de que o objetivo da ciência é a verdade aparece apenas em seus escritos a partir de 1957; tudo o que apregoa em sua Logik Forschung é que a busca da verdade pode ser uma motivação psicológica para os cientistas.

De uma atividade como um jogo nada se exige de parecido com o requisito da busca de justificação epistêmica ou da legitimação instrumental, já que tudo se resume ao objetivo de vencer uma partida ou um campeonato. A pretensão de validar as regras do método apoiando-as em práticas consagradas de pesquisa, ou apontando a confiabilidade epistêmica dos resultados produzidos por sua adoção, envolve assumir um posicionamento metametodológico para o qual é difícil encontrar paralelo nos jogos. A situação em que o cientista reconhece a refutação de uma teoria é diferente da de um xeque-mate na medida em que sua teoria pode ter malogrado pela detecção de um contraexemplo independentemente da proficiência com que a teoria foi formulada. No caso do enxadrista, a derrota é pessoal se fruto do cometimento de um erro ou se resultante da superioridade do adversário:

Dedicando-se à ciência normal, o pesquisador é um solucionador de quebra-cabeças, não um testador de paradigmas. Embora possa, durante a busca de solução para um quebra-cabeça particular, tentar vários enfoques alternativos rejeitando os que falham em produzir o resultado desejado, ele não está testando o paradigma quando faz isso. Ao contrário, ele é como o jogador de xadrez que, diante do problema posto [...] ensaia vários movimentos alternativos em busca de solução. As tentativas feitas pelo jogador de xadrez ou pelo cientista servem para testá-lo, não as regras do jogo. (KUHN, 1970, p. 206-7)

Para aceitar que sua teoria foi refutada, o cientista precisa estar convencido, no plano metametodológico, da cogência da regra que lhe prescreve tomar a decisão de abandoná-la. Pode sempre se perguntar pela conveniência de acatá-la no curso específico de uma pesquisa. Isso é diferente do que ocorre em jogos como o xadrez nos quais as regras são aplicadas automaticamente sem a possibilidade de avaliações contextuais. Se a ciência fosse fruto de regras constitutivas, a condução da pesquisa - independentemente de se na física, química, sociologia, psicologia e alhures - teria de ser feita com o emprego dos mesmos procedimentos metodológicos. Os jogadores se submetem às mesmas regras por mais que exibam variável poder de encontrar saídas, solucionar desafios e quebra-cabeças. As regras que tornam possíveis jogos como o xadrez definem os passos permissíveis sem predefinir os gambitos. Se as regras do método fossem constitutivas, os modos de fazer ciência seriam previamente definidos por mais que a destreza das "jogadas", as manobras escolhidas, varie entre os pesquisadores. Fossem as regras do método constitutivas, o filósofo não teria justificativa para acalentar a pretensão de formulá-las e embasá-las. Seria despropositado propor filosoficamente regras para $a$ ciência se as que a historicamente a organizaram fosse constitutivas. Bastaria conhecê-las, saber quais são como ocorre quando se deseja praticar um jogo - ou descrever sua atuação em um plano metametodológico. Nesse caso, a teoria prescritiva do método elaborada pelo filósofo seria extrínseca à ciência e a descritiva padeceria de redundância.

Diferentemente do que ocorre nos jogos, na ciência não basta que alguém conheça as (supostas) regras de seu jogo para praticá-la. Para se credenciar a participar da produção científica, o pesquisador precisa conhecer a fundo os conteúdos específicos da tradição da qual sua pesquisa faz parte. Por mais que a geração 
dos conteúdos tenha sido viabilizada pela adoção de determinados procedimentos, não se justifica tomar por demonstrada a separação entre a dimensão metodológica e a substantiva. À diferença dos jogos, as regras que um pesquisador adota podem influenciar o tipo de resultado que porventura venha a alcançar. Isso quer dizer que a opção por uma metodologia como a refutacionista define maneiras de lidar com os conteúdos explicativos diferentes das resultantes da adoção de regras vinculadas a outros modelos metodológicos como, por exemplo, o bayesiano.

\subsection{SERÃO REGULATÓRIAS AS REGRAS DO MÉTODO?}

Se as regras do método científico forem, seguindo a supracitada conceituação de Searle, de tipo regulatório, revela-se ainda mais problemática a comparação da ciência com jogo. Regras regulatórias - como as de etiqueta ou de boas maneiras - são introduzidas para reger uma atividade preexistente sem que se possa considerá-las indispensáveis ao fim último visado por determinada prática ou atividade. Podem contribuir para que determinada modalidade de atividade seja executada com (mais) eficiência, urbanidade, elegância etc., mas não a criam. Diversamente das regras constitutivas que precisam ser sempre essencialmente as mesmas para que (a identidade de) uma atividade - caso do jogo - seja preservada, as regulatórias podem variar histórica e culturalmente. Podem buscar se ajustar a objetivos variáveis, à realização de determinados valores ou à perseguição específica de certos tipos de resultado. Se o conhecimento científico for fruto da adoção de regras do método que historicamente se revelaram proficientes - e que foram mantidas em razão dos resultados que propiciam - compará-lo com jogo perde força. Caso sejam regulatórias, as regras adotadas na ciência admitem alternativas.

Supor que na ciência a pressão pura e simples da comunidade sobre os especialistas seja suficiente para que regras sejam obedecidas ou postas em prática equivale a negar que a ciência tenha uma racionalidade epistêmica além de uma funcionalidade social. Caso seja praticada com base em regras de natureza regulatória, a ciência é uma modalidade de atividade que não deixaria de existir mesmo que regras do método, em contraposição com os modos assistemáticos de pensar do senso comum, jamais tivessem sido formuladas. Assim como algumas regras têm sido coletivamente adotadas por se revelarem importantes para melhorar o convívio social, e não como imposições resultantes da tirania dos costumes, as regras do método podem ser, caso tenham natureza regulatória, propostas com base na suposição de que propiciam maior confiabilidade epistêmica aos resultados.

Caso a ciência seja regida por regras regulatórias, é mais fácil compreender por que surgem dificuldades para identificá-las acompanhando as variadas e desniveladas práticas de pesquisa nas diversas ciências nos diferentes momentos de suas respectivas histórias. As tentativas de apreender a natureza da regulação a que a pesquisa científica está efetivamente submetida não chegam a um consenso porque os procedimentos adotados nas diversas ciências não são os mesmos e resistem às tentativas de unificação. O fisicalismo representa o paroxismo das propostas de unificação metodológica carentes de lastro na variegada realidade exibida pelas ciências. A universalidade metodológica é artificialmente postulada por um sistema de regras que ignora a indomável riqueza e variedade dos procedimentos de pesquisa postos em prática pelas diferentes ciências. É como se o antropólogo falasse universalmente de costumes desconsiderando singularidades presentes na sociedade que estuda.

A proliferação de teorias do método é fomentada menos pela diversidade nos modos de se fazer ciência e mais por ismos epistemológicos o mais das vezes com manifestos pendores prescritivistas. A multiplicação de metaciências é desorientadora porque não reflete a variedade de regras em uso nas ciências. Se regulatórias, como muitas das encontráveis no espaço da convivência social, as regras do método admitem variação em relação às efetivamente atuantes. Nesse caso, é mais justificável concebê-las, à maneira de Popper, como convenções. No entanto, desponta inútil uma profusão de propostas normativas, já que a maioria se mostra disfuncional por estar descolada da realidade, seja ela social ou científica. No caso de as regras serem regulatórias, a ação de identificá-las pode envolver algum grau de dificuldade, mas não a ponto de justificar a 
complexa atividade reconstrutiva a que se tem dado o nome de filosofia da ciência. É cabível pensar que o filósofo da ciência tem historicamente se dedicado à formulação de regras de tipo regulatório só que defendidas como se fossem constitutivas.

Em termos antropológicos, regras regulatórias podem ser facilmente apreendidas se não fizerem parte de uma sociedade muito diferente da nossa. A dificuldade não reside propriamente em identificá-las, mas em apreender precisamente sua função tendo em vista que podem desempenhar funções manifestas e latentes em um mesmo contexto ou momento histórico. Não havendo como lhes atribuir universalidade, podem favorecer a defesa do relativismo, cognitivo e/ou cultural. Se as regras do método forem regulatórias, aquele que estuda a ciência, que teoriza sobre ela, precisará buscar se familiarizar com o diversificado universo das práticas de pesquisa com o objetivo de detectar as regras em uso. A constatação de que subsiste uma diversidade de procedimentos nas várias ciências pode levar água para o moinho de uma modalidade de convencionalismo metametodológico para o qual todas as regras em uso são igualmente aceitáveis. A ambição de aperfeiçoar as regras que vêm sendo adotadas esbarraria no fato de que "novas regras" só teriam efetividade caso se formasse em torno delas um consenso no âmbito da comunidade científica que levasse a colocá-las em prática. Substituir regras regulatórias envolve a restrição essencial de que precisam se adequar aos fins visados pela atividade a ser regulada. Boas maneiras à mesa não devem entrar em conflito com a finalidade de se alimentar e se sentir saciado.

Menos propícia a promover a comparação da ciência com jogo, a visão de que as regras do método são de tipo regulatório, de que podem variar historicamente a ponto de ser justificável pensar em alternativas, é mais compatível com o convencionalismo metametodológico e até com uma versão sociológica, quiçá sociologisita, do mesmo. Sem falar que a natureza regulatória das regras dificulta ou mesmo inviabiliza a pretensão de integrá-las em uma teoria geral do método (científico). Isso talvez explique a tendência do filósofo da ciência a deixar de vê-las como regulatórias para poder pensá-las de modo descontextualizado e para a elas conferir caráter universal.

O desinteresse do cientista em discutir o que promove a prevalência de um conjunto de procedimentos metodológicos em detrimento de outro pode se dever, conforme argumenta Kuhn, ao fato de as regras serem do paradigma, de muitas se manterem em operação apenas durante a sua vigência. Como quem trabalha sob a égide do paradigma não experimenta a necessidade de avaliar procedimentos metodológicos - nem os que acompanham o paradigma nem possíveis alternativas -, deixa de haver espaço para uma discussão geral sobre a questão do método. As regras do método deixam de ter importância crucial não só em virtude de o alcance de sua jurisdição normativa ficar circunscrita ao paradigma como também por se mostrarem incapazes de previamente fornecerem as coordenadas e as diretrizes para a pesquisa científica. Sendo as regras do método encaradas como dependentes do contexto teórico, passam a ser vistas como indissociáveis dos conteúdos cuja justificação tradicionalmente foi atrelada à aplicação da metodologia correta. Local e contextualmente formuladas, as regras possuem natureza regulatória. Observe-se, contudo, que a possibilidade de recomendar a adoção de regras regulatórias diferentes das que estão em uso deixa de ser viável caso o método seja, como advoga Kuhn, dependente do paradigma em que é empregado:

Se as regras metodológicas e os e objetivos visados são simplesmente convenções, e se ocorre (como Kuhn e Feyerabend mostraram) de os cientistas frequentemente discordarem sobre os objetivos e métodos da ciência, disso se segue que as disputas metodológicas, e todas as discordâncias substantivas sobre o mundo que envolvem metodologias divergentes, não podem ser racionalmente encerradas. (LAUDAN, 1996, p. 16)

Só o acompanhamento das variegadas práticas de pesquisa encontráveis em ciências tão diferentes quanto as naturais e as sociais pode permitir uma ampla identificação das regras regulatórias em operação. Se as regras do método só podem ser metacientificamente apreendidas, pelo acompanhamento da ciência real, é questionável a pretensão de epistemologicamente estabelecê-las. Guardadas as diferenças, a ambição de regular a ciência ignorando (a diversidade de) sua realidade é parcialmente equivalente à proposta de estatuir regras de conduta elegante à mesa que dificultem a realização do fim perseguido: alimentar-se. As 
regras regulatórias despontam portadoras de normatividade frouxa no caso de se poder alcançar determinado fim sem acatá-las ou sem que seu desrespeito seja seguido de sanções. Quem deixa de ter modos polidos à mesa pode sofrer pressão social, mas não é proibido de comer em culturas como a nossa. Se dos diferentes sistemas de regras formulados pelos filósofos nenhum consegue se provar indispensável é como se estivessem sendo propostas diferentes "regras de etiqueta" que, sem a força da pressão social, se mostrassem incapazes de moldar a atividade-fim.

Aplicamos a distinção de Searle entre regras constitutivas e regulatórias por acreditarmos que possui fecundidade heurística sem, porém, deixarmos de reconhecer que é problemático separá-las rigidamente em virtude de as regras constitutivas também cumprirem, ainda que complementarmente, função similar à das regulatórias. Sem falar que definem formas consideradas apropriadas de conduta. Na disputa de uma partida, quem desrespeita conscientemente as regras de um jogo, com ou sem intenção fraudulenta, também viola regras regulatórias de convivência social. Por mais que não tenham o poder ontológico de criar "realidades", as regras regulatórias acrescentam facetas ou traços aos comportamentos, que inexistiriam sem elas. Não deixam por isso de também ter poder constitutivo. A diferença é a de que não criam sistemas inteiros de comportamento, porém em parte recriam as formas existentes de conduta. Por mais que não gerem comportamentos ex nihilo, dão origem a novos tipos de ação ao submeterem os comportamentos existentes a ritos que os modificam.

Os diferentes modos de o empirista e o racionalista encararem a relação entre ciência e senso comum ajudam a pensar a natureza - constitutiva ou regulatória - das regras do método. À maneira da maioria dos empiristas, Einstein (1959, p. 290) encara "toda a ciência como nada mais sendo que um refinamento do modo cotidiano de pensar". Sendo o conhecimento senso comum corrigido e metodizado, como propõe Hume, não representa uma ruptura com os modos comuns de pensar. Por essa óptica, as regras da ciência não criam uma "entidade", não dão origem a uma forma completamente nova de abordar e explicar os fatos. São regras regulatórias cuja adoção não implica ir de encontro ao senso comum, mas introduzir mecanismos mais confiáveis de construção e validação de teorias e explicações. Sendo assim, as regras e procedimentos de pesquisa que a ciência acrescentou aos modos de pensar do senso comum cumprem função mais parecida com a das regras de etiqueta do que com a das regras de xadrez. Popper tem uma visão da relação entre ciência e senso comum que, próxima da empirista, dificulta a comparação da ciência com o xadrez e torna problemática a caracterização das regras do método como constitutivas, como sendo do mesmo tipo das dos jogos.

Em contraposição, o racionalismo é mais compatível com a concepção de que a ciência é regida por regras constitutivas. De Descartes a Bachelard (1966, p.132; 1949b, p. 10) predomina no seio do racionalismo a visão de que o conhecimento (científico) marca sempre uma ruptura com o senso comum. O conhecimento é sempre de objetos construídos, nunca de objetos percebidos. A crença de que a ciência constrói explicativamente o objeto, de que só ela se mostra apta a fazê-lo, envolve a postulação de procedimentos especiais para isso. Descartes (1950, p. 48) opõe a ideia astronômica de sol, matematicamente construída, às especiosas percepções do senso comum do astro-rei. Com base nesse tipo de visão, as regras do método são exclusivas à ciência e a constituem por serem indispensáveis para que a ciência se capacite a elaborar explicações que representam uma descontinuidade com os modos "desregrados", "imediatistas" e "sensoriais" de o senso comum lidar com os fatos. Essa óptica rupturista, fundamental para atribuir natureza constitutiva às regras, não é perfilhada por Popper (1959, p. 18) que "concorda que o conhecimento científico é mero desenvolvimento do conhecimento ordinário, ou do conhecimento de senso comum".

É importante ter presente que se as regras do método científico, conforme pensadas pelos racionalistas, têm natureza constitutiva - como as dos jogos - resulta difícil compreender por que não as identificam de modo consensual. Mesmo porque deveriam ser apreensíveis sem necessidade de acompanhar a grande variedade de atividades e práticas chamadas de ciência. Fosse esse o caso, inexistiria razão para filosoficamente colocar em discussão as regras do método e muito menos para intentar aprimorá-las e reformulá-las.

Popper faz a justificação da adoção de seu sistema de convenções repousar precipuamente na desqualificação das alteridades. Rechaçando esse tipo de démarche, Feyerabend coloca todas as convenções em pé de igualdade para chegar ao anarquismo epistemológico. Com isso, Feyerabend extrai do convencionalismo 
metametodológico a consequência de que inexistem boas razões para desmerecer regras alternativas. Tirante a argumentação epistemológica de que é inatingível a verificação cabal de um universal categórico, o convencionalismo metametodológico carece de autoridade para questionar as convenções atreladas à verificabilidade com critério de cientificidade. No plano puramente convencional, é problemática a concessão de universalidade à metodologia refutacionista e a desqualificação in limine da possibilidade de acolhimento de procedimentos metodológicos alternativos. Levando às últimas consequências o convencionalismo metametodológico, Feyerabend (2002, p. 231) chega ao anarquismo em nome do qual advoga que cada pesquisador pode adotar as regras que lhe aprouver.

Se as regras possuem natureza regulatória, nenhuma é indispensável para a ciência existir, de tal modo que sua adoção pode ser consensual sem que sejam ontologicamente necessárias para que se forme uma atividade como científica. Contra o convencionalismo metametodológico, Pandit (1991, p. 204) observa que não há como "propor nem justificar regras metodológicas simplesmente aconselhando o rechaço ou a proibição do uso de possíveis alternativas a elas". Isso quer dizer que a defesa do modelo hipotético-dedutivo não pode depender crucialmente do rechaço da indução, dos riscos envolvidos nas inferências ampliativas. Os defeitos das alteridades são insuficientes para justificar uma constelação específica de convenções. É questionável que Popper, ficando adstrito ao plano estrito das convenções, tenha sido bem-sucedido em seu projeto de desenvolver uma alternativa metodológica, representada pelo modelo hipotético-dedutivo, à indução que justifique tirá-la de cena. Sem falar que é controverso que seu próprio sistema metodológico, vendo-se obrigado a recorrer ao conceito de corroboração, dispense o emprego de inferências de tipo quase-indutivo.

Se as regras do método fossem constitutivas precederiam as práticas científicas, conduziriam seus passos e seriam universalmente reconhecidas e acolhidas, uma vez que só lograriam fazer ciência os que as adotassem, só alcançariam bons resultados os que as seguissem à risca. Em alguns jogos, as regras podem ser desrespeitadas, no sentido de violadas, acarretando punições, mas não desconsideradas, uma vez que, isso ocorrendo, não haveria jogo. Em contraposição, se as regras do método tiverem natureza regulatória podem em tese ser substituídas. Como as novas terão de ser formuladas e propostas para atividades de pesquisa já sob regulação precisam se mostrar aptas a melhor organizar as práticas, a lapidar os procedimentos que vêm sendo empregados. Sendo assim, a proposição de regras ou recomendações não poderá ignorar a diversidade dos modos de conduzir a pesquisa nas variadas e desniveladas ciências. Não poderá desconsiderar as profundas diferenças nos modos de fazer pesquisa encontráveis nas ciências naturais e sociais. O filosofo da ciência, ou mesmo o metodólogo, terá de assumir uma postura similar ao do antropólogo diante de uma cultura diferente da sua. Defrontando-se com modos de convivência que lhe pareçam "rústicos", o antropólogo jamais propõe, por exemplo, que regras que fazem parte de sua forma de vida substituam as encontradas na sociedade que estuda.

As regras de um jogo, como o xadrez, viabilizam sua prática, mas não se confundem com ele. O que se pode e o que não se pode fazer nem de longe determinam a variedade e a riqueza de jogadas, de gambitos. Não há prática social sem convenções cuja função consiste em deixar em aberto - uma vez definido o que é obrigatório respeitar para que o jogo possa ser praticado - um amplo conjunto de movimentos possíveis. As poucas regras do xadrez devem ser rigidamente acatadas, mas as jogadas podem variar enormemente, indo das mais simples e elementares às mais inventivas e sofisticadas. Visto que o respeito a convenções gera padrões comportamentais na pesquisa, é injustificável conceder monopólio regulamentador às adotadas sem excogitar o que as alternativas ensejariam. A necessidade de aferir as convenções para que se justifique preferir umas em detrimento de outras acarreta extrapolar o campo da mera tomada de decisão. Isso explica por que se continua a fazer filosofia $d a$ ciência e não apenas sociologia da ciência. 


\section{REFERÊNCIAS BIBLIOGRÁFICAS}

BACHELARD, Gaston. The Philosophical Dialectic of the Concepts or Relativity. In: Schilpp, P. (org.) Albert Einstein: Philosopher-Scientist. Evanston: The Library of Living Philosophers, 1949.

BACHELARD, Gaston. La Philosophie du Non: Essai d'une Philosophie du Nouvel Esprit Scientifique. 4a.edição. Paris: Les Presses Universitaires de France, 1966.

BLOOR, David. Knowledge and Social Imagery. Chicago: The University of Chicago Press, 1991.

CARNAP, Rudolf. The Elimination of Metaphysics through Logical Analysis of Language. In: Ayer, A. (org.) Logical Positivism. Nova Iorque: The Free Press, 1959.

CARNAP, Rudolf. The Logical Syntax of Language. Trad. de Amethe Smeaton. Londres: Routledge \& Kegan Paul, 1949.

CARNAP, Rudolf. The Logical Structure of the World. Trad. de Rolf George. Berkeley. California: University of California Press, 1967.

DESCARTES, René. Méditations Métaphysiques. Paris: Librairie Larousse, 1950.

DURKHEIM, Emile. Les Règles de la Méthode Sociologique. Paris: Presses Universitaires de France, 1967.

EINSTEIN, Albert. Physics and Reality. In: Ideas and Opinions. Trad de Sonja Bargmann. Nova Iorque: Crown Publishers, 1959.

FEYERABEND, Paul. Against Method. Londres. Verso, 2002.

HEIDEGGER, Martin. The Question Concerning Technology and Other Essays. Trad de William Lovitt. Nova Iorque: Garland Publishing. 1977.

HUME, David. An Inquiry Concerning Human Understanding. Chicago: Encyclopedia Britannica, 1952.

KUHN, Thomas. The Structure of Scientific Revolutions. In: Neurath, O. Carnap, R. \& Morris, C. (orgs.) Foundations of the Unity of Science. Vol. II. Chicago: The University of Chicago Press, 1970.

LAKATOS, Imre. History of Science and Its Rational Reconstructions. In: Worrall, J. \& Currie, G. (orgs.) Imre Lakatos Philosophical Papers. Vol. I: The Methodology of Scientific Research Programmes. Cambridge: Cambridge University Press, 1981.

LAKATOS, Imre. Falsification and the Methodology of Scientific Research Programmes. In: Lakatos \& Musgrave (orgs.) Criticism and Growth of Knowledge. Cambridge: Cambridge University Press, 1977.

LAKATOS, Imre. Popper On Demarcation and Induction. In: The Philosophy of Karl Popper. Illinois: The Open Court Publishing, 1974.

LAUDAN, Larry. Beyond Positivism and Relativism: Theory, Method and Evidence. Oxford: Westview Pres, 1996.

LAUDAN, Larry. Theories of Scientific Method from Plato to Mach: A Bibliographical Review. In: History of Science, 7: 1, p. 1-63. 1968.

LAUDAN, Larry. Science and Relativism: Some Key Controversies in the Philosophy of Science. Chicago: The University of Chicago Press, 1990.

LAUDAN, Larry. Science and Values. Berkeley: University of California Press, 1984.

MCMULLIN, Ernest. Philosophy of Science and Its Rational Reconstructions'. In: Radnitzky, G. \&Andersson, G (orgs.) Progress and the Rationality of Science. Dordrecht: Reidel, 1978.

NOLA, Robert \& SANKEY, Howard (orgs). A Selective Survey of Theories of Scientific Method. In: After Popper, Kuhn and Feyerabend. Recent Issues in Theories of Scientific Method. Dordrecht: Kluver, 2000.

PANDIT, G. L. Methodological Variance: Essays in Epistemological Ontology and the Methodology of Science. Dordrecht: Kluwer, 1991.

PEIRCE, Charles. How to Make our Ideas Clear. In: Charles S. Peirce: Selected Writings. Nova Iorque: Dover, 1958.

POINCARÉ, Henri. La Science et L'Hypothèse. Paris. Flammarion, 1968. 
POPPER, Karl. The World of Parmenides: Essays on the Presocratic Enlightenment. Londres: Routledge, 1998.

POPPER, Karl. Replies to my Critics. In: The Philosophy of Karl Popper. Part II. La Salle: Open Court, 1974a.

POPPER, Karl. Autobiography of Karl Popper. In: The Philosophy of Karl Popper. Part I. La Salle: Open Court, 1974b.

POPPER, Karl. The Logic of Scientific Discovery. Londres: Hutchinson, 1959.

POPPER, Karl. Realism and the Aim of Science. Postscript to the Logic of Scientific Discovery. Londres: Routledge, 1996.

POPPER, Karl. The Open Society and its Enemies. Vol. I. Londres: Routledge and Kegan Paul: 1986.

POPPER, Karl. The Open Society and its Enemies. Vol. II. Nova Jersei: Princenton University Press, 1971.

POPPER, Karl. Conjectures and Refutations: The Growth of Scientific Knowledge. Londres: Routledge, 1989.

REICHENBACH, Hans. Experience and Prediction: An Analysis of the Foundation and the Structure of Knowledge. Chicago: The University of Chicago Press, 1976.

SAUSSURE, Ferdinand. Cours de Linguistique Générale. Paris: Payot \& Rivages, 1995.

SEARLE, John. Speech Acts. An Essay in the Philosophy of Language. Londres: Cambridge University Press, 1969.

SEARLE, John. How to Derive "Ought" From "Is". The Philosophical Review. Duke University Press. Vol. 73, No. 1, p. 43-58, Jan/1964.

WITTGENSTEIN, Ludwig. Lectures: Cambridge, 1932-1935. Organizado por Alice Ambrose. Amhwerst: Prometeus, 1979.

WITTGENSTEIN, Ludwig. Philosophical Investigations. Trad. de G. E. M. Anscombe. Oxford: Blackwell Publishing, 1968. 